\title{
Early Miocene gastropod and ectothermic vertebrate remains from the Lesvos Petrified Forest (Greece)
}

\author{
Katerina Vasileiadou ${ }^{1}$ (D) Madelaine Böhme $^{2}$ Thomas A. Neubauer ${ }^{3,4}$. \\ Georgios L. Georgalis $^{5,6}$ • George E. Syrides ${ }^{7}$ - Lambrini Papadopoulou ${ }^{8}$. \\ Nickolas Zouros ${ }^{1,9}$
}

\begin{abstract}
The Lesvos Petrified Forest (western Lesvos, Greece) has long been famous for its plant fossils. Recently, one proboscidean (from the Gavathas locality) and seven micromammalian species (from the Lapsarna locality) were described; these were the first animals to be found in the Early Miocene subtropical forest. For the first time, a fauna of gastropods and ectothermic vertebrates from the Lapsarna locality is now available. This fauna derives from lacustrine sediments under the pyroclastic
\end{abstract}

Katerina Vasileiadou

k.vasileiadou@geo.aegean.gr

1 Natural History Museum of the Lesvos Petrified Forest, 17 8th November Str., 81100 Mytilene, Lesvos, Greece

2 Fachbereich Geowissenschaften, Eberhard Karls Universität, Sigwartstraße 10, 72076 Tübingen, Germany

3 Geological-Paleontological Department, Natural History Museum Vienna, Burgring 7, 1010 Vienna, Austria

4 Department of Animal Ecology and Systematics, Justus Liebig University, Heinrich-Buff-Ring 26-32 IFZ, 35392 Giessen, Germany

5 Department of Geosciences, University of Fribourg, Chemin du Musée 6, 1700 Fribourg, Switzerland

6 Department of Earth Sciences, University of Torino, Via Valperga Caluso 35, 10125 Turin, Italy

7 Laboratory of Geology and Palaeontology, School of Geology, Faculty of Sciences, Aristotle University of Thessaloniki, 54124 Thessaloníki, Greece

8 Department of Mineralogy-Petrology-Economic Geology, School of Geology, Faculty of Sciences, Aristotle University of Thessaloniki, 54124 Thessaloníki, Greece

9 Department of Geography, University of the Aegean, 81100 Mytilene, Lesvos, Greece material that contains the petrified plants. Based on fragmented mollusc remains, isolated fish pharyngeal teeth and utricular otoliths (lapilli), fragmented amphibian vertebrae and a tooth-bearing element, and reptile fragmented dentaries, teeth, osteoderms and vertebrae, the presence of eight freshwater and three terrestrial gastropod species, three freshwater cyprinid species, and two amphibian and five reptile taxa has been confirmed. Stratigraphical and radiometric data suggest an age older than $18.4 \pm 0.5 \mathrm{Ma}$ (latest Early Miocene), in good agreement with the faunal composition. This paper is the first report of the concurrent presence of three cyprinid fish species in a Greek Early Miocene locality, as well as the first documentation of an Early Miocene proteid amphibian in southeastern Europe. The present findings represent one of the best-documented Early Miocene gastropod and fish faunas in the Aegean/southern Balkans, thus adding to our knowledge of Early Miocene amphibians and reptiles from that region and providing valuable information on the local subtropical ecosystem.

Keywords Gastropoda Cyprinidae $\cdot$ Amphibia $\cdot$ Reptilia . Taxonomy $\cdot$ Early Miocene

Kurzfassung Der versteinerte Wald von Lesvos (Lesbos) in Griechenland ist schon lange für seine Pflanzenfossilien bekannt. Kürzlich wurden auch eine Rüsseltier- (von der Lokalität Gavathas) sowie sieben Kleinsäuger-Arten (von der Lokalität Lapsarna) als erste Tiere des untermiozänen subtropischen Waldes beschrieben. Erstmalig ist nun eine Fauna von Gastropoden und ektothermischen Vertebraten von der Lokalität Lapsarna verfügbar, aus lakustrinen Sedimenten unterhalb des pyroklastischen Materials, welches die versteinerten Pflanzen enthält. Basierend auf fragmentierten Molluskenresten, isolierten Schlundzähnen 
und Otolithen (Lapilli) von Fischen, fragmentierten Wirbeln und einem zahntragenden Element von Amphibien, sowie fragmentarischen Zahnbeinen, Zähnen, Osteodermen und Wirbeln von Reptilien konnten acht Süßwasser- und drei Landschnecken-Arten, drei cyprinide SüßwasserfischArten, zwei Amphibien-Arten und fünf Reptilien-Arten nachgewiesen werden. Stratigraphische und radiometrische Daten deuten ein Alter von mehr als 18,4 \pm 0,5 Ma (spätes Unter-Miozän) an, mit dem auch die Faunenzusammensetzung gut übereinstimmt. Diese Arbeit ist der erste Nachweis des gleichzeitigen Vorkommens von drei cypriniden Fisch-Arten in einer untermiozänen griechischen Fundstelle, sowie die erste Dokumentation einer untermiozänen proteiden Amphibie in südosteuropäischem Gebiet. Die vorliegenden Funde stellen eine der am besten dokumentierten untermiozänen Fauna von Gastropoden und ektothermischen Vertebraten des Ägäis-/SüdbalkanRaumes dar, erweitern die Kenntnis untermiozäner Amphibien und Reptilien dieser Region und liefern dabei wertvolle Informationen über das lokale subtropische Ökosystem.

Schlüsselwörter Gastropoda · Cyprinidae · Amphibia · Reptilia · Taxonomie · Unter-Miozän

\section{Introduction}

One of the most renowned geological monuments in the Aegean area, the Lesvos Petrified Forest, which covers a large part of western Lesvos Island (also known as Lesbos) in Greece (Fig. 1), has been providing information on the Early Miocene subtropical flora of the Aegean-Anatolian area for many decades. The petrified tree trunks, branches,

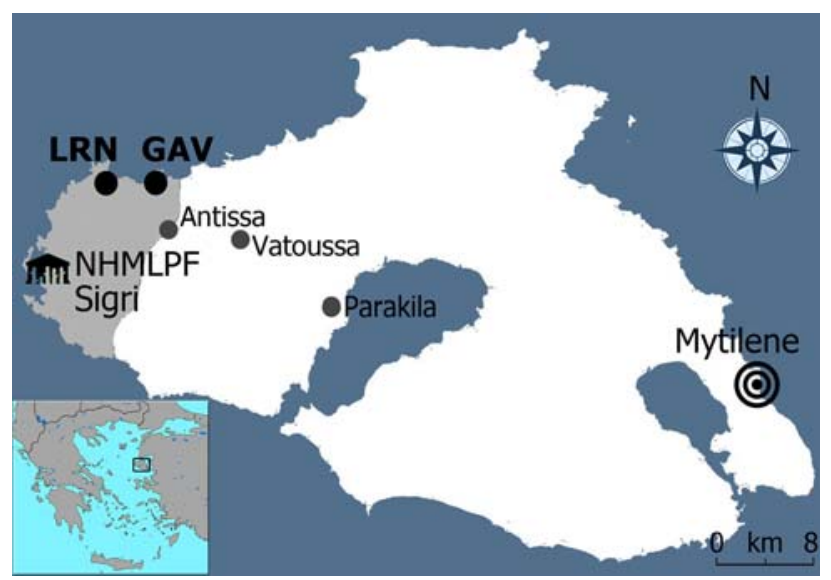

Fig. 1 Lesvos Island in the NE Aegean Sea. $G A V$ fossiliferous locality of Gavathas, $L R N$ fossiliferous locality of Lapsarna, NHMLPF Natural History Museum of the Lesvos Petrified Forest; the dark grey color shows the protected area of the Lesvos Petrified Forest and cones as well as the leaf prints preserved inside successive layers of pyroclastic material in this region have attracted human interest since antiquity. As far back as the third century B.C., the fossils in this petrified forest were mentioned by the Lesvian philosopher Theophrastus-who is often considered the father of botany-in his book $\Pi \varepsilon \rho i$ $\tau \tilde{\omega} \nu \lambda_{1} \theta 0 u \mu \varepsilon \hat{v} \omega \nu$ (On Things Turned to Stone). During the nineteenth century, the petrified trees of Lesvos were mentioned by, among others, Unger (1845, 1847). More recently, numerous studies have presented details of the taxonomy of plant fossils from Lesvos (e.g., Velitzelos et al. 1981a, b; Velitzelos and Zouros 1998; Zouros et al. 2004, 2007).

The pyroclastic material covering the western part of Lesvos and the Lesvos Petrified Forest has not yet revealed any animal fossils. However, lacustrine sediments underlying the volcaniclastic rocks have yielded a number of important animal fossils. Lower cheek teeth of the proboscidean Prodeinotherium bavaricum (Meyer, 1831) were found in 1999 near the village of Gavathas (Fig. 1: GAV), indicating a minimum age of $18.4 \mathrm{Ma}$ (latest Early Miocene) (Koufos et al. 2003). In addition, a large number of microfossils, including gastropods and isolated elements of fish, amphibians, reptiles and micromammals, were located in a thin layer of blackish-brown marls exposed near the village of Lapsarna (Fig. 1: LRN) (Vasileiadou and Zouros 2012). The micromammalian fossils from Lapsarna have been attributed to Chiroptera indet., Erinaceidae indet., Soricidae indet., Eumyarion aff. latior/weinfurteri, Democricetodon sp., and Glirulus cf. diremptus (Vasileiadou and Zouros 2012).

This work presents the results of a study of gastropod and ectothermic vertebrate remains from the locality of Lapsarna. The fossils described in this work coexist in the sampled lacustrine sediments with Early Miocene micromammalian teeth (Vasileiadou and Zouros 2012), indicating that the fossils and the teeth are of the same age. This fauna is very important as no other gastropod or ectothermic vertebrate faunas with comparable species richness from the Early Miocene of the southern Balkans and the Aegean area have been described.

\section{Geological settings and locality}

The fossiliferous locality of Lapsarna is located on a rural earth road southeast of the village Lapsarna, and lies within the Gavathas-Lapsarna Basin in the northwestern part of Lesvos Island (Fig. 1: LRN; GPS coordinates: $39.257^{\circ} \mathrm{N}$, $25.931^{\circ} \mathrm{E}$ ). Its exposure along the roadcut is restricted to only $\sim 2 \mathrm{~m}$. The basal infill of the Gavathas-Lapsarna Basin comprises a sequence of Neogene lacustrine deposits containing several lignite-rich layers a few centimetres to $1 \mathrm{~m}$ thick (Fig. 2; Mourouzidou 2001; Koufos et al. 2003). 


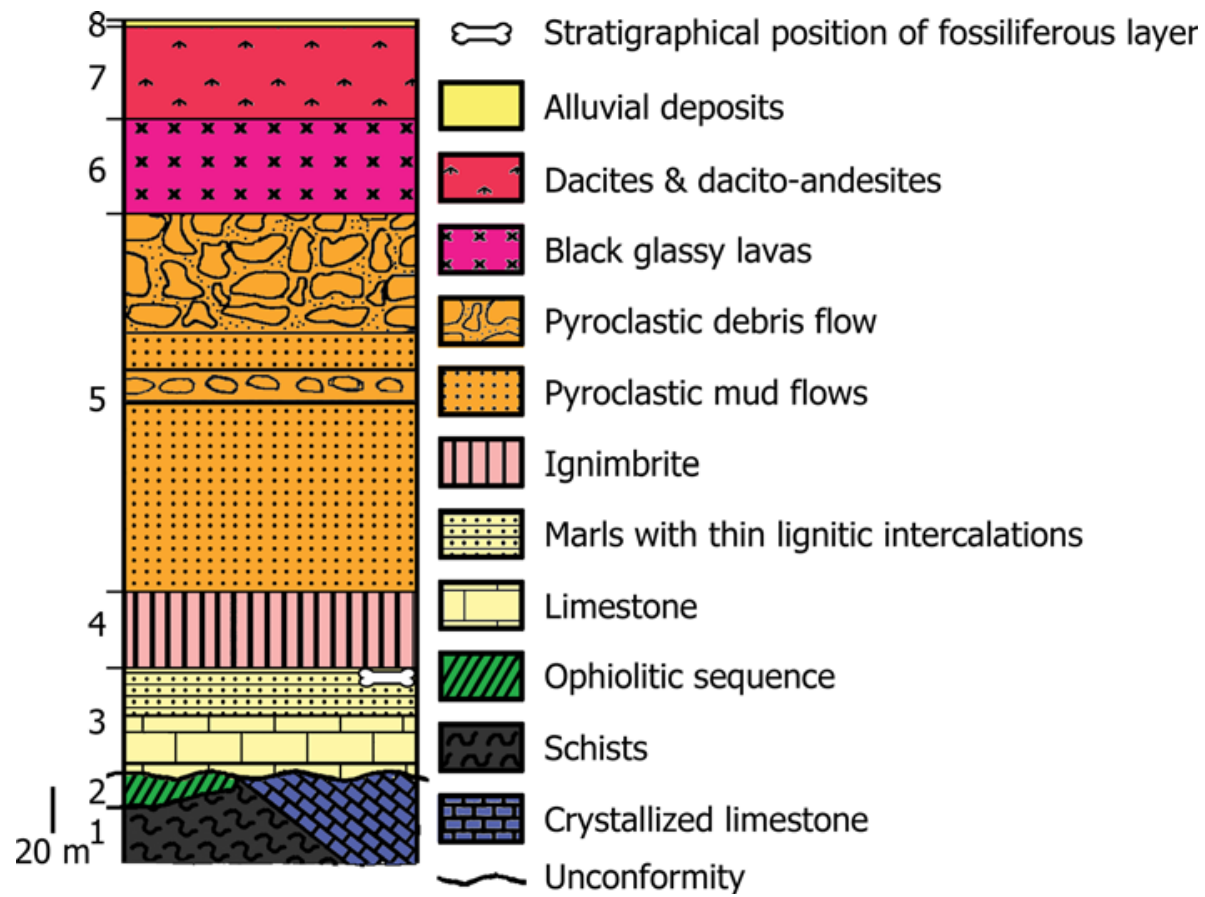

Fig. 2 Synthetic stratigraphical column with the rock types in western Lesvos (after Mourouzidou 2001 and Koufos et al. 2003, modified). 1 Neopaleozoic-Triassic basement rocks (mainly schists, phyllites and carbonate rocks); 2 Tectonic nappe of the ophiolitic sequence overthrusting the previous unit; 3 Neogene lacustrine deposits (alternating strongly silicified marly limestones and marls with thin lignitic intercalations); 4 lower ignimbrite (small lava conglomerates and volcanic ashes); 5 pyroclastic deposits (mud flows with a debris flow in the upper part); 6 upper ignimbrite (black glassy

The approximately 20 -cm-thick fossiliferous layer at Lapsarna is stratigraphically postioned in the upper part of these deposits and consists of blackish-brown marls that are very rich in organic matter. The lacustrine deposits of the basin are overlain by a thick sequence of volcanic rocks, which include a lower ignimbrite layer, a pyroclastic sequence hosting the plant fossils of the Lesvos Petrified Forest, an upper ignimbrite, and the Lava Unit (Katsikatsos et al. 1986; Mourouzidou 2001; Koufos et al. 2003). The lower ignimbrite, the pyroclastic deposits, and upper ignimbrite correspond to the Acid Volcanics Unit of Pe-Piper (1980) (Koufos et al. 2003).

The precise age of the fossiliferous layer has not yet been established with confidence. The micromammalian fauna shows close affinities with the Early Miocene Greek faunas from Karydia and Aliveri (Vasileiadou and Zouros 2012), both of which are correlated with the Neogene Mammal unit MN 4 (Doukas 2003 and Hoek Ostende et al. 2015, respectively). According to Pe-Piper and Piper (1993), the Acid Volcanics Unit is approximately synchronous with the Skoutaros Formation (Fm). The Fm has been defined as a normally magnetised sequence of andesite and basalt flows, lacking in hydrous mineral phases, lavas); 7 Lava Unit (dacites and dakito-andesites); 8 recent alluvial deposits. The white bone shows the vertical position of the Lapsarna fossiliferous layer in the upper part of the Neogene lacustrine deposits in the Gavathas-Lapsarna Basin. Layers 4-6 correspond to the Acid Volcanic Unit of Pe-Piper (1980). Details on the geological setting and characteristics of the LRN locality, as well as maps, photographs of the sampled section and a synthetic stratigraphical column of western Lesvos can be found in Vasileiadou and Zouros (2012)

which can be found east of the Gavathas-Lapsarna Basin, northeast of Antissa and in the area of Vatoussa (Fig. 1) (Pe-Piper and Piper 1993). Those authors applied a radiometric date of $18.4 \pm 0.5 \mathrm{Ma}$, which was actually based on andesite samples from the area of Parakila (almost $50 \mathrm{~km}$ southeast of Lapsarna, Fig. 1) dated by Borsi et al. (1972) to the lower part of the Skoutaros Fm and, thus, also to the lower part of the Acid Volcanics Unit. Consequently, thuis age would be the latest possible age for the underlying lacustrine deposits containing the fossiliferous layer (Koufos et al. 2003; Vasileiadou and Zouros 2012).

\section{Materials and methods}

The sampled material was screen-washed through $0.5-\mathrm{mm}$ mesh sieves and the residues were air-dried. The fossils were picked out of the residues manually. They were studied in the Geography Department, University of the Aegean (Lesvos, Greece); in the Laboratory of Geology and Palaeontology, Aristotle University of Thessaloniki (Greece); and in the Palaeontological Museum of Munich (Germany). Collections of fossil and recent fish lapilli that 
were used for comparisons belong to the Bavarian State Collection for Palaeontology and Geology (Munich, Germany; BSPG). The SEM images of the fossils were taken uncoated under low-vacuum conditions using a JEOL JSM6390LV scanning electron microscope at the Laboratory of Electron Microscopy of the Aristotle University of Thessaloniki (Greece).

Gastropod taxonomy follows Bouchet and Rocroi (2005), Wade et al. (2006) and the FreshGEN database (Neubauer et al. 2014). The terminology and the morphotypes for the fish pharyngeal teeth follow Nakajima (1984), Böhme (2002) and Pasco-Viel et al. (2010). The right half tooth formulae are presented whenever needed. The orientations and terminology of the fossil fish lapilli follow Schulz-Mirbach and Reichenbacher (2006) and the linea basalis on the ventral side is after Assis (2005). The maximum length and width of the lapilli were measured following Schulz-Mirbach and Reichenbacher (2006). Taxonomy follows Pyron and Wiens (2011) for Amphibia, Brochu (2000) for Crocodylia and Gauthier et al. (2012) for Squamata, whereas anatomical terminology follows Estes (1981) for Caudata, Sanchiz (1998) for Anura, Steel (1973) for Crocodylia, and Estes (1983) and Rage (1984) for Squamata.

Measurements were carried out under a WILD M4000 microscope equipped with a LANG MCL-2, $\mathrm{x}-\mathrm{y}$, $50 \times 50 \mathrm{~mm}$, micrometric electronic table (accuracy $0.001 \mathrm{~mm}$ ), at the Geology Department, Aristotle University of Thessaloniki (Greece).

The material is deposited at the Natural History Museum of the Lesvos Petrified Forest (Lesvos, Greece).

\section{Systematic palaeontology}

Class Gastropoda Cuvier, 1798

Order Littorinimorpha Golikov and Starobogatov, 1975

Superfamily Truncatelloidea Gray, 1840

Family Bithyniidae Gray, 1857

Genus Bithynia Leach, 1818

\section{Bithynia sp.}

Figure $3 \mathrm{a}-\mathrm{c}$

Material. 22 complete calcareous opercula and several operculum fragments.

Description. The opercula show a large number of alternating indistinct and stronger concentric growth lines.

Comments. The shape and morphology of the opercula are characteristic for the genus Bithynia. It is very possible that many of the fragmented gastropod shells included in the sampled material may also belong to Bithynia. However, the absence of complete specimens with diagnostic features does not permit even a tentative attribution of any shell to the genus. Identification to species level based only on opercula is impossible.

In Greece, B. (Pseudemmericia) rubella was described as a new species from the Middle Miocene deposits of the Nenita Fm in Chios by Schütt and Besenecker (1973) based on complete shells; according to those authors, its operculum does not differ from those of the extant type of the subgenus (Bithynia pseudemmericia Schütt, 1964).

Extant Bithynia lives in a great variety of habitats, ranging from standing to moderately flowing, usually richly vegetated, and sometimes even temporarily drying water bodies (Glöer 2002; Welter-Schultes 2012).

Family Emmericiidae Brusina, 1870

Genus Emmericia Brusina, 1870

Emmericia sp.

Figure $3 \mathrm{~d}-\mathrm{g}$

Material. 1 complete shell, more than 15 fragmented shells.

Description. The only complete shell is compressed and the initial shape is distorted. The protoconch, consisting of roughly one whorl, is rather large, flat and smooth. The teleoconch includes three slightly convex whorls. The second whorl shows very faint growth lines, which become stronger along the surfaces of the subsequent whorls. Weak spiral striae appear after the second whorl and become more prominent on the last half-whorl. The area of the umbilicus is deformed and its characteristics remain unknown. The aperture looks rather broad, the lips are continuous and thickened, whereas the outer lip is posteriorly curved. Some of the specimens show a groove along the outer lip.

Comments. The specimens from Lesvos can be attributed to Emmericia based on the large and flat protoconch and the typically thickened and curved lips; however, the preservation of the material does not allow identification to the species level.

According to Harzhauser and Mandic (2008), the extant genus Emmericia seems to have made its first appearance in the late Early to early Middle Miocene of the Dinaride Lake System (see also Brusina 1870). Therefore, the present record is among the earliest of the genus. Modern Emmericia species are native to Italy and the Balkans and inhabit springs and rivers, as well as caves and subterranean habitats (Glöer 2002; Vavrova 2010).

Family Hydrobiidae Stimpson, 1865

? Genus Bania Brusina, 1896

? Bania sp.

Figure $3 \mathrm{j}-\mathrm{O}$

Material. More than 25 mostly fragmented specimens. 


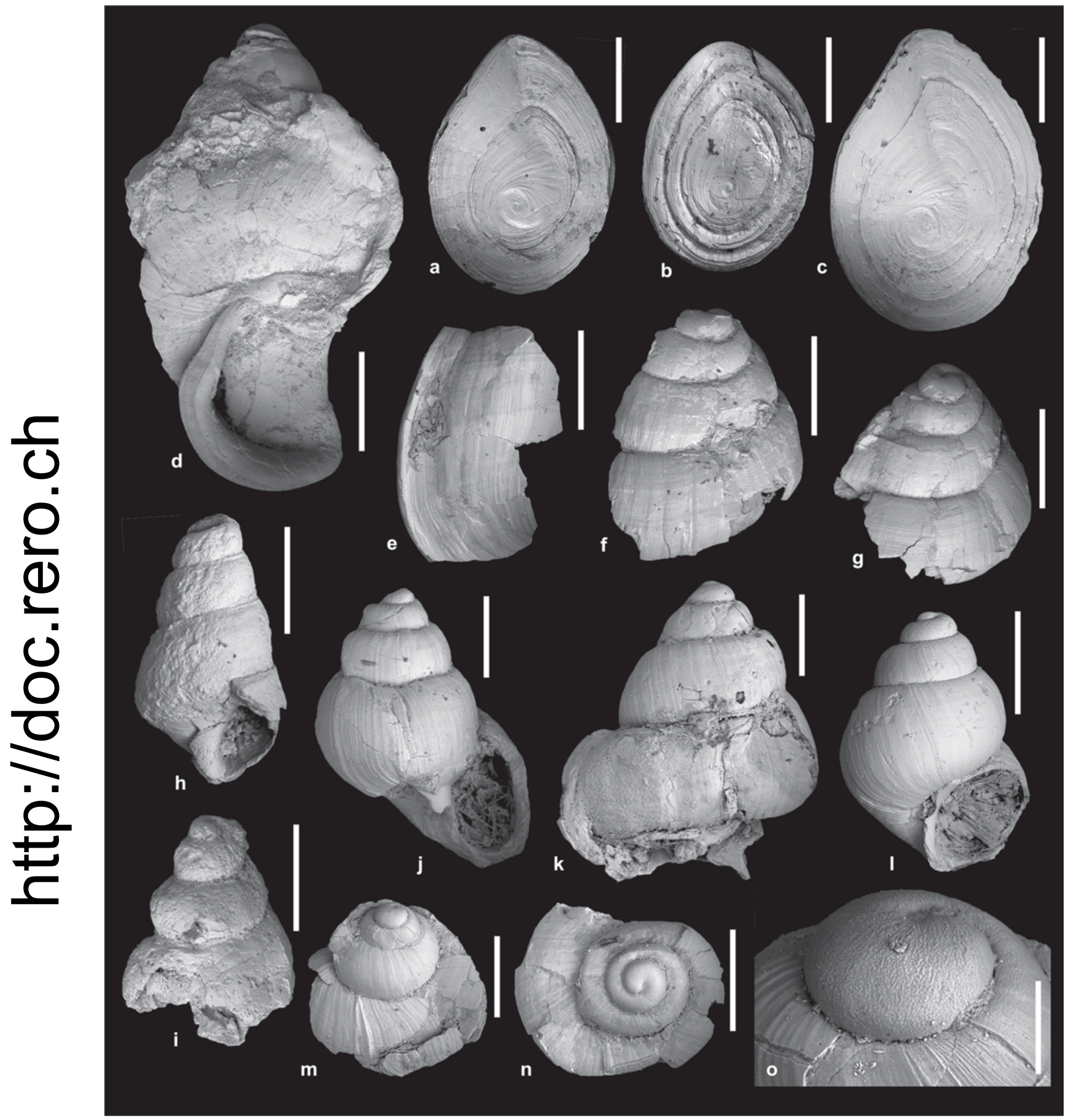

Fig. 3 Freshwater truncatelloid Gastropoda from Lapsarna, Lesvos Island, Greece. Bithynia sp. opercula: $a$ LRNg-22; $b$ LRNg-25; c LRNg-21; Emmericia sp.: $d$ LRNg-10; e LRNg-13; $f$ LRNg-4; $g$ LRNg-3. Hydrobiidae indet.: $h$ LRNg-31; $i$ LRNg-32; note that the specimen of $i$ shows, quite misleadingly, a deeper suture than that of

$h$, which is a result of deformation rather than a morphological difference; ? Bania sp.: $j$ LRNg-55; $k$ LRNg-57; $l$ LRNg-65; $m$ LRNg43; $n$ LRNg-45; $o$ LRNg-43, protoconch of $m$; scale bars equal $1 \mathrm{~mm}$ $(a-g), 0.5 \mathrm{~mm}(h-n)$ and $0.1 \mathrm{~mm}(o)$ 
Description. The protoconch is small, with a maximum diameter of $0.25 \mathrm{~mm}$, and consists of a little more than one whorl. It has a slightly inflated apex, with a width of around $0.1 \mathrm{~mm}$. The surface of the protoconch is strongly granular and the transition to the teleoconch is marked by the termination of the granular structure and the onset of thin, dense and strong growth lines. The largest specimens attain three and half whorls. The whorls are strongly convex and the sutures are moderately deep. After the initiation of the second teleoconch whorl, faint spiral lines are present in some specimens. The aperture is subcircular and touches the base of the preceding whorl; it leaves a narrow, slit-like umbilicus.

Comments. In comparison with the co-occurring indeterminate taxon of Hydrobiidae, this species is more bulbous and has a deeper suture. Its broad shape and granular, sharply terminated protoconch is reminiscent of several early Middle Miocene representatives of the fossil genus Bania. The abovementioned characteristics are typical of B. gobanzi (Frauenfeld, 1864) from the Rein Basin in Austria (Harzhauser et al. 2014a), as well as B. torbariana (Brusina, 1874) from the Sinj Basin in Croatia (Neubauer et al. 2011). The specimen illustrated in Fig. $3 \mathrm{j}$ resembles Bania stosiciana (Brusina, 1874) from the Drniš Basin in Croatia in terms of the stepped outline and the prominent growth lines (Neubauer et al. 2016). Because of these similarities, we tentatively assign the present species to that genus. Given the protoconch sculpture, an affiliation with Emmericiidae or Bithyniidae, which expose entirely smooth juvenile shells (see e.g. Neubauer et al. 2011, 2013a, 2016), can be excluded. None of the hydrobiid species reported from the Middle Miocene of Chios by Schütt and Besenecker (1973) match the morphology of the current specimens.

\section{Hydrobiidae indet.}

Figure 3h, i

Material. 3 fragmented specimens.

Description. Three fragmented specimens are available: one comprises the protoconch and two whorls of the teleoconch, whereas the other two miss the apex and consist only of three whorls, which are moderately convex. They are very small and slender, with a rather acute spire. The sutures are moderately shallow. Their surfaces are strongly corroded and no sculpture can be observed. The area of the umbilicus and aperture is missing.

Comments. The quite nonspecific morphology makes a more precise identification as well as any comparison with the many coeval hydrobioid species arbitrary.

Clade Panpulmonata Jörger et al., 2010

Order Hygrophila Férussac, 1822
Superfamily Lymnaeoidea Rafinesque, 1815

Family Lymnaeidae Rafinesque, 1815

? Genus Radix Montfort, 1810

? Radix sp.

Figure $4 \mathrm{a}-\mathrm{c}$

Material. At least seven specimens and several fragments.

Description. All specimens are broken and most of them are also compressed and strongly deformed. The total number of whorls is unknown; the most complete specimens consist of the protoconch and two teleoconch whorls. The protoconch is smooth, consists of ca. one whorl, and its transition to the teleoconch is marked by the initiation of faint growth lines. The preserved teleoconch whorls are separated by shallow sutures, show low convexity and increase quickly in diameter. Their surfaces bear weak to sometimes prominent growth lines.

Comments. This species is tentatively classified as a member of the genus Radix because of its relatively short spire and the fast increase in diameter. Further comparisons and identification at the species level are again hampered by the incompleteness of the material. Therefore, a potential relationship with $R$. calavardensis (Bukowski, 1896) from the middle Miocene of Chios Island, Greece, reported by Schütt and Besenecker (1973), has to be confirmed based on better preserved material.

Above all, shells of recent Radix species show enormous variation that is - at least partly-ecologically influenced, which is why species determination based on shell morphology alone is very difficult (Schniebs et al. 2011).

Extant Radix species mostly prefer standing to slowly moving waters with rich vegetation; they are found in creeks, streams, lakes, ponds and old river arms, dwelling on plants, stones and sandy or muddy bottoms (WelterSchultes 2012).

\section{Lymnaeidae indet.}

Figure 4d-f

Material. At least 18 specimens and several fragments.

Description. No complete specimens have been found and the total number of whorls is unknown. The largest specimen consists of the protoconch and 2.5 teleoconch whorls (Fig. 4d). The shell is slender and elongated, with a relatively high spire. The protoconch is smooth, comprises slightly more than one whorl, and its transition to the teleoconch is marked by the initiation of faint growth lines. The teleoconch whorls are fairly convex and increase slowly in size. The growth lines are faint on the first teleoconch whorl and become stronger on the surfaces of the following whorls. The sutures are moderately deep. Aperture and umbilicus are unknown. The LNR material 


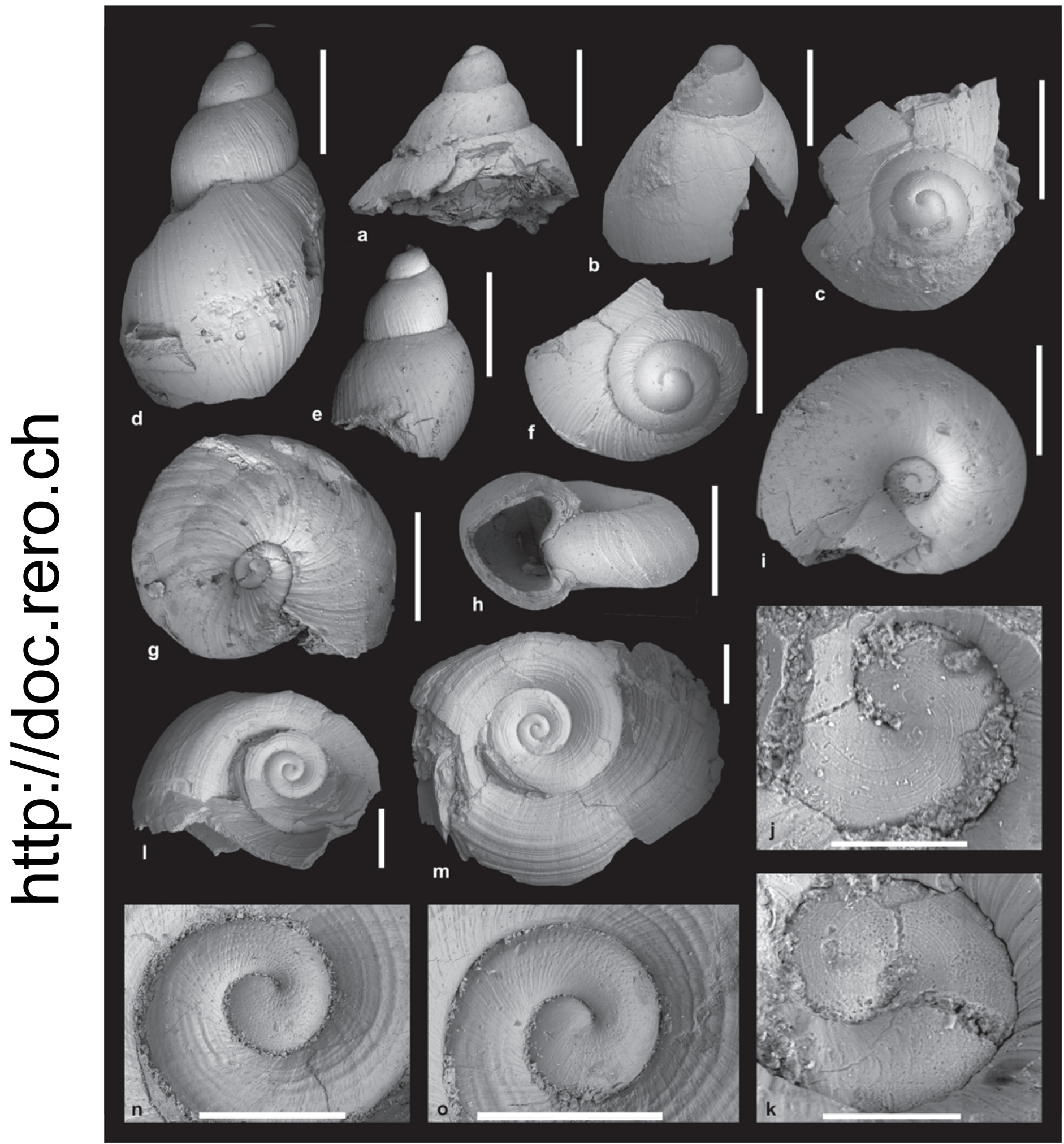

Fig. 4 Freshwater pulmonate Gastropoda from Lapsarna, Lesvos Island, Greece. ? Radix sp.: $a$ LRNg-93; $b$ LRNg-94; $c$ LRNg-95, apical view; Lymnaeidae indet.: $d$ LRNg-71; $e$ LRNg-81; $f$ LRNg-81, apical view; Gyraulus sp.: $g$ LRNg-110; $h$ LRNg-30; $i$ LRNg-127;

$j$ LRNg-101, protoconch; $k$ LRNg-110, protoconch of $g$; Planorbarius sp.: $l$ LRNg-141; $m$ LRNg-142; $n$ LRNg-141, protoconch of $n$; $o$ LRNg-142, protoconch of $m$. Scale bars equal $1 \mathrm{~mm}(a-f, l-m)$, $0.5 \mathrm{~mm}(g-i, n, o)$ and $0.1 \mathrm{~mm}(j, k)$ 
also includes a few elongate columellar fragments, which may belong here.

Comments. A precise identification is hampered by the incompleteness of the material, but the slender morphology is reminiscent of species of Omphiscola and Stagnicola. Galba, e.g. the Middle Miocene G. gaudryi from the Langhian deposits of the Nenita Fm in Chios Island (Schütt and Besenecker 1973), has distinctly more convex whorls that often produce a stepped spire.

Superfamily Planorboidea Rafinesque, 1815

Family Planorbidae Rafinesque, 1815

Genus Gyraulus Charpentier, 1837

Gyraulus sp.

Figure $4 \mathrm{~g}-\mathrm{k}$

Material. At least 31 specimens and several fragments.

Description. Due to high degree of fragmentation, no specimen comprises more than 2.5 teleoconch whorls. The spire is immersed. The protoconch consists of slightly less than one whorl and bears 5-6 spiral striae (Fig. 4j, k). The transition from the protoconch to the teleoconch is indicated by the termination of the spiral striae and the onset of growth lines, which are faint on the first teleoconch whorl and much stronger on the following whorls, and strongly prosocyrt on the apical side. The second teleoconch whorl increases rapidly in height and diameter and strongly overlaps the preceding one. A blunt angulation appears in lateral view. The aperture is unknown, but the opening of the most complete specimens is symmetric and heartshaped, with convex margins and a sheet-like inner lip.

Comments. Gyraulus skhiadicus (Bukowski, 1896), originally described from the late Middle Miocene to early Late Miocene of Rhodes and also reported from Early and Middle Miocene layers at Chios island by Schütt and Besenecker (1973), is flatter and exposes a pronounced angulation above whorl mid-height. Willmann (1981) considered that species a junior synonym of $G$. doricus (Bukowski, 1896), described from the same layers as G. skhiadicus exposed at the Monastery Skhiadi, and differing solely in the stronger expression of the angulation, forming a distinct keel.

The shell illustrated in Fig. 4 h resembles G. pulici (Brusina, 1897) from the early Middle Miocene of the Gacko Basin (Neubauer et al. 2013b) in terms of size and the position and expression of the angulation. Differences are the wider coiling and the unsymmetrical shape of the aperture of $G$. pulici. It is also reminiscent of G. albertanus (Clessin, 1877) from the Middle Miocene of southern Germany (e.g. Gall 1972; Salvador and Rasser 2014). Although the wide geographic distance without interjacent occurrences makes a closer relationship unlikely, more and better-preserved material is required to clarify this issue.
Most extant Gyraulus species live in still or slowly running waters that are usually highly vegetated, and feed on detritus and/or algae (Welter-Schultes 2012).

Genus Planorbarius Duméril, 1805

Planorbarius sp.

Figure 41-0

Material. More than 10 specimens.

Description. They are the largest specimens in the LRN mollusc assemblage. All specimens are broken and many are compressed. The whorls are rounded, slightly flattened on the umbilical side, increase regularly in diameter, and are separated by deep sutures. The total number is unknown; the most complete specimen attains 3.5 whorls. The protoconch consists of roughly one whorl bearing the typical spiral rows of circular pits (Fig. 4n, o). The transition to the teleoconch is marked by the cessation of the circular pits and the onset of faint growth lines and strong spiral striae. The latter gradually fade on succeeding whorls but cover the entire teleoconch (as preserved) on both the apical and umbilical sides. Preserved fragments of the peristome show that it is simple and sharp; some of these also exhibit faint spiral striae.

Comments. The size of the shell and the teleoconch sculpture undoubtedly classify the present species as a Planorbarius. Schütt and Besenecker (1973) reported $P$. mantelli (Dunker, 1848) from Chios, which generally matches the present species. However, the incompleteness of our material makes identification to the species level impossible. In any case, the taxonomy and relationships of fossil Planorbarius species of Europe are very poorly resolved and require careful revision (Harzhauser et al. 2014a, b).

The widespread extant Planorbarius corneus (Linnaeus, 1758), which is morphologically close to the LRN Planorbarius, prefers stagnant to slowly running waters rich in aquatic plants, and feeds on detritus (WelterSchultes 2012).

Superorder Eupulmonata Haszprunar and Huber, 1990 Superfamily Helicoidea Rafinesque, 1815

Family Helicidae Rafinesque, 1815

Helicidae indet.

Figure 5a, b

Material. 25 specimens.

Description. All 25 available specimens are fragmentary and consist only of the upper part of the spire, showing the protoconch, whereas a few of them also include small parts of the teleoconch, without, however, giving any indication of the total number of whorls. The preserved specimens indicate a very low spire with an almost flat apex. The 


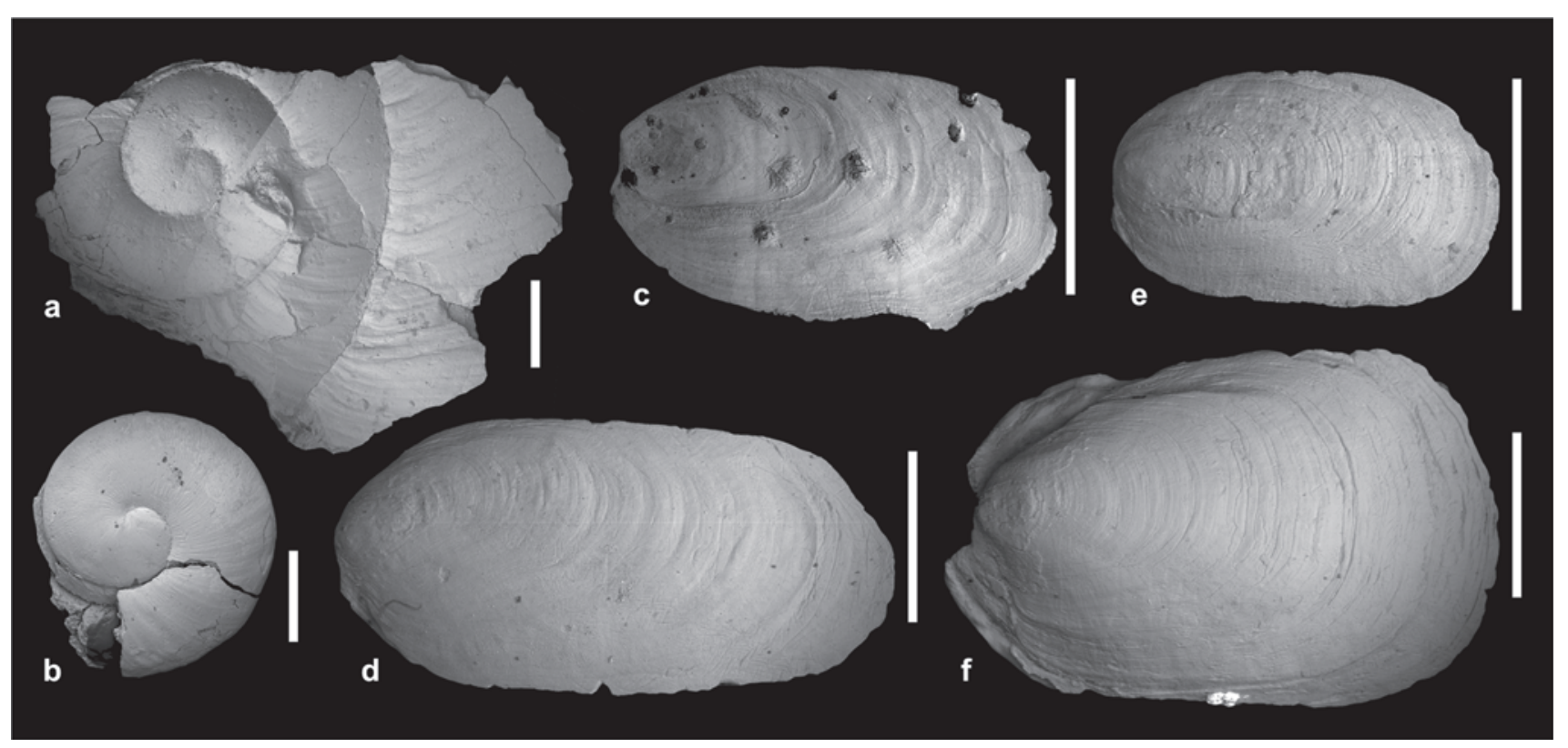

Fig. 5 Terrestrial gastropods from Lapsarna, Lesvos Island, Greece. Helicidae indet.: $a$ LRNg-151; $b$ LRNg-152; note that $a$ was restored from two separate SEM images, resulting in some graphical issues;

initial part of the protoconch is small, but the shell diameter increases quickly afterwards. The surface of the protoconch is almost smooth, showing numerous very thin and delicate riblets in a few specimens (Fig. 5b); riblets are visible close to the sutures. The transition to the teleoconch is indicated by a gradual transition from the delicate riblets into broad and blunt growth lines, starting shortly after the onset of the second whorl. The specimen illustrated on Fig. 5a suggests flattened teleoconch whorls. Growth lines on the teleoconch are occasionally prominent, forming weak ribs.

Comments. The small initial part of the protoconch and the pattern of numerous faint riblets are strikingly reminiscent of a species from the late Early Miocene of Austria attributed to the genus Pleurodonte Fischer von Waldheim, 1807 by Binder (2004). That genus, however, has a modern distribution in the Caribbean and northern South America, which is why neither species is likely to by closely related to Pleurodonte (pers. comm. Binder, 2015). The similarities of the fossil species to that genus are probably a result of convergence. The generic attribution of the Lesvos species remains unresolved; however, many other helicid genera common in the Miocene, such as Tropidomphalus, Pseudochloritis, and Helicigona, differ in the presence of prominent papillae on the protoconch or have an entirely smooth protoconch, like Megalotachea (e.g. Binder 2002, 2008). More and better-preserved material is required for a more detailed determination and confirmation of the present, tentative classification.

Superfamily Limacoidea Lamarck, 1801

Family Milacidae Ellis, 1926
Limax sp.: c LRNg-183; d LRNg-181; Milax sp.: e LRNg-172; $f$ LRNg-171. Scale bars equal $1 \mathrm{~mm}$

Genus Milax Gray, 1855

Milax sp.

Figure $5 \mathrm{e}, \mathrm{f}$

Material. 10 vestigial shells.

Description. The shells are roughly elliptical, thick and almost symmetric. In lateral view, the shell is dome-shaped already in early ontogeny, with the nucleus situated at the middle of the anterior border, surrounded by concentric growth lines.

Comments. The generic classification is based on the broad, dome-shaped, subsymmetrical shape. The genus has been reported already from the latest Early Miocene of Austria (Binder 2004) and the Middle Miocene of southern Germany (Salvador et al. 2015) and Hungary (Gaál 1911; Kókay 2006). Since the diagnosis of slug species is based on soft body characteristics, a more precise identification is impossible.

Extant species of Milax are mostly adapted to habitats close to the Mediterranean coasts and live exclusively on the ground (Welter-Schultes 2012).

Family Limacidae Lamarck, 1801

Genus Limax Linnaeus 1758

\section{Limax sp.}

Figure 5c, d

Material. 11 vestigial shells.

Description. The vestigial shells available are elongated elliptical; large specimens are convex in lateral view, the 
small ones are almost flat. The nucleus is situated at the anterior margin and distinctly decentralised, resulting in a strongly asymmetrical shell. Prominent concentric growth lines emerge from the nucleus. The lateral margins run almost parallel to each other and the posterior margin is elongated and rounded.

Comments. The internal shells of limacids are of limited taxonomical value as they do not offer diagnostic features that can separate them at species level; it is often difficult to attribute them even to genus (Binder 2004).

Recent members of Limax comprise large slugs that show exclusively nocturnal activity and feed in particular on lichens, fungi and dead plant material (Nitz 2013). Limax species live in a large variety of habitats, but prefer damp leaf litter (Welter-Schultes 2012). Their geographic distribution covers Europe, with the highest species diversity found in southern Europe, mainly the Mediterranean region, and in the Alpine region (Nitz 2013).

Class Actinopterygii Cope, 1887

Order Cypriniformes Bleeker, 1859

Family Cyprinidae Cuvier, 1817

Genus Palaeoleuciscus Obrhelova, 1969

\section{Palaeoleuciscus sp.}

Figure $6 \mathrm{a}-\mathrm{h}$

Material. One fragmented pharyngeal bone with teeth (LRNt-424); 29 isolated pharyngeal teeth (LRNt-401-423, 425-430); 2 fragments of pharyngeal bone without teeth (LRNt-431-432); 62 lapilli (24 left: LRNl-14, 22, 101, 117, $125,145,167,169,214,224,236,245,257,275,308,313$, 329, 335, 345, 346, 361, 364, 367, 391; 38 right: LRNl-1, 24, 39, 44, 102, 112, 127, 130, 131, 140, 144, 146, 147, $160,161,188,189,193,205,210,219,225,228,240,255$, $273,280,309,318,326,332,337,341,365,369,376,379$, 390).

Description of pharyngeal dentition. The only toothed pharyngeal bone in the material is fragmented and bears three very slender and small teeth arranged on one row and one even smaller dorsally (Fig. 6a: arrow shows the only tooth of the second row preserved). The teeth-both those on the pharyngeal bone and the isolated ones-are laterally compressed and form a hook at the tip (Fig. 6a-e). The medial crest is usually slightly serrated. Both crests run from the hook towards the tooth base, bordering a narrow and elongated mastication surface that forms a very small angle with the longitudinal axis of the teeth. The material also includes five small peg-like teeth which possibly correspond to the A5 (Fig. 6e). The majority of the teeth are slender and delicate, with distal width measured on the grinding surface ranging from $0.163 \mathrm{~mm}$ (on the toothed pharyngeal bone) to $0.39 \mathrm{~mm}$, whereas there are also teeth
Fig. 6 Freshwater fish remains from Lapsarna, Lesvos Island, Greece; pharyngeal teeth in occlusal view, unless otherwise specified; lapilli in dorsal view unless otherwise specified; all lapilli are shown as left ones, the right ones are specified as mirrored. Palaeoleuciscus sp.: $a$ LRNt-424, left pharyngeal bone; $b, c$ LRNt-408, right pharyngeal tooth ( $b$ posterior view); $d$ LRNt-404, right pharyngeal tooth; $e$ LRNt-428, possibly right A5 pharyngeal tooth (posterior view); $f$ LRN1-188, right lapillus (mirrored); $g$ LRN1-367, left lapillus; $h$ LRN1-326, right lapillus in ventral view (mirrored); Barbus s.l.: $i$ LRNt-888, A5 or A4 pharyngeal tooth; $j$ LRNt-883, A5 or A4 pharyngeal tooth (lateral view); $k$ LRNt-494, A1 pharyngeal tooth; $l$ LRNt-487, A1 pharyngeal tooth; $m$ LRNt-488, B/C pharyngeal tooth; $n$ LRNt-540, A2/A3 pharyngeal tooth; $o$ LRNt-538, B/C pharyngeal tooth; $p$ LRNt-501, B/C pharyngeal tooth; $q$ LRNl-216, left lapillus; $r$ LRN1-139, right lapillus (mirrored); $s$ LRN1-32, left lapillus; $t$ LRN1-331 left lapillus in ventral view. Scale bar equals $1 \mathrm{~mm}$

that are large and robust (distal width $0.62-0.86 \mathrm{~mm}$ ). However, there are also some teeth of intermediate size (distal width $0.43-0.50 \mathrm{~mm}$ ). Thus, we cannot clearly distinguish two separate size groups in the material that would lead us to conclude the presence of two species; the difference in size is most possibly the result of the presence of teeth originating from fish at different ontogenetic stages.

Description of lapilli. The anterior margin of the lapilli is rounded and the posterior part is trapezoidal (Fig. 6f-h). The four edges are well developed and the posterior part shows symmetry, as the anterolateral and anteromedial edges are located opposite each other. The lateral, medial and posterior margins are flat. The posterior margin is often vertical and forms the posteriormost part of the lapilli; in a few specimens, the posteromedial edge is slightly more prominent and forms the posteriormost part of the lapilli; on some others, the posterolateral edge is more prominent. The cranial umbo is medium to strong in the large specimens and weaker in small ones. The mineralization area is strong in large specimens and sometimes also visible in dorsal view. The linea basalis is V-shaped, with a small crenulation in its medial part (Fig. 6h). The measurements are given in Table 1.

Comparisons. The LRN teeth show many similarities to Palaeoleuciscus teeth from the Early and Middle Miocene of Europe (described by Gaudant et al. 2002; Böhme 2010). Of special importance is the serrated medial crest, which distinguishes the leuciscin genus Palaeoleuciscus from the otherwise similar phoxinin genus Palaeorutilus (Böhme 2008).

The LRN lapilli have been compared with recent lapilli of Leuciscus leuciscus from wild catches in Germany (BSPG 2003 IV 86a and b, 141a and b), those of cf. Leuciscus from Starnberger See (BSPG 2003 IV 136b), and fossil lapilli of Palaeoleuciscus sp. from Le Locle (BSPG 


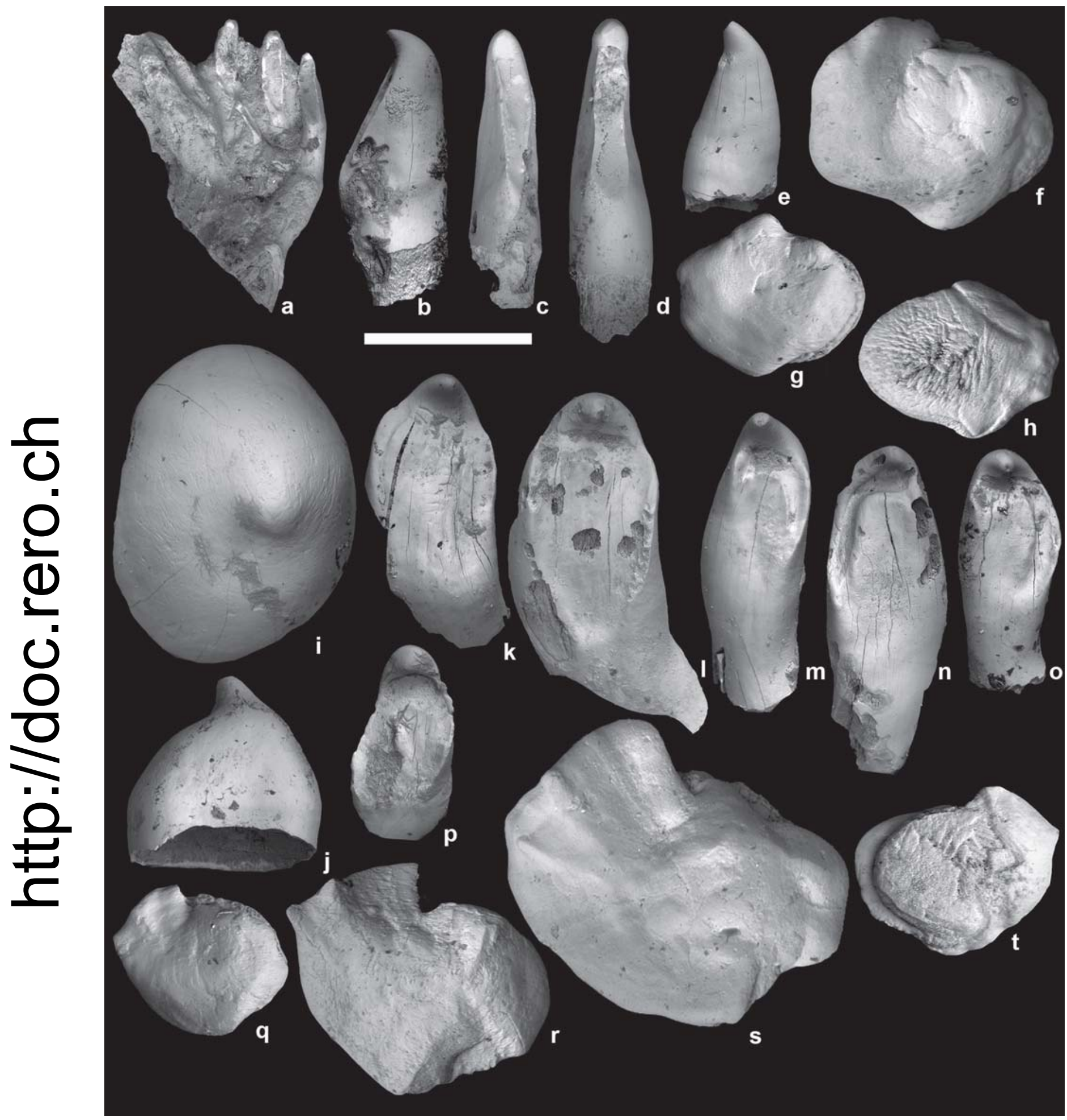

2003 XVIII 47-50, figured in Schulz-Mirbach and Reichenbacher 2006: Fig. 26) and of Palaeoleuciscus sp. 1 from Mauensee (BSPG 2003 XVIII 84-89, figured in Jost et al. 2007: Fig. 5). The LRN lapilli are morphologically similar to the recent lapilli from Germany. The lapilli of
Palaeoleuciscus sp. from Le Locle display a much thicker mineralised area and dorsal lobe and a thin posterior part, whereas the LRN lapilli of a similar size show a flatter dorsal side and almost equally thick anterior and posterior lobes. Furthermore, the Le Locle specimens are less 
Table 1 The minimum, mean and maximum values (in $\mathrm{mm}$ ) of the maximum length and maximum width and the length/width ratio of the Palaeoleuciscus sp. and Barbus s.l. lapilli, following Schulz-Mirbach and Reichenbacher (2006)

\begin{tabular}{|c|c|c|c|c|c|c|c|c|c|c|}
\hline \multirow[t]{2}{*}{ Taxon } & \multirow[t]{2}{*}{$N$} & \multicolumn{3}{|c|}{ Length (mm) } & \multicolumn{3}{|c|}{ Width (mm) } & \multicolumn{3}{|c|}{ Length/width } \\
\hline & & Min. & Mean & Max. & Min. & Mean & Max. & Min. & Mean & Max. \\
\hline Palaeoleuciscus & 61 & 0.87 & 1.03 & 1.29 & 0.7 & 0.87 & 1.26 & 0.99 & 1.19 & 1.34 \\
\hline Barbus s.1. & 67 & 0.87 & 1.14 & 1.92 & 0.68 & 0.95 & 1.84 & 1.01 & 1.2 & 1.37 \\
\hline
\end{tabular}

$N$ number of complete specimens

symmetrical than the LRN ones, as the anteromerial edge is anteriorly situated. The LRN lapilli are closer morphologically to those from Mauensee described as Palaeoleuciscus sp. 1, but they are somewhat thinner. Just like with the otoliths from Le Locle, Wannenwaldtobel 2 and Mauensee, the otoliths from Lapsarna are identified as Palaeoleuciscus sp. because they are similar to lapilli of extinct Leuciscus and they co-occur in the sediments with the pharyngeal teeth from Palaeoleuciscus.

Comments. Palaeoleuciscus is an extremely abundant Early to Late Miocene (Burdigalian-early Tortonian, MN 3-MN 9) genus; complete skeletons or isolated pharyngeal teeth and otoliths from species of this genus have been reported from a large number of localities in Germany, Switzerland, Austria, Czech Republic, France, Spain, Armenia, Serbia, Bulgaria and Turkey (Böhme and Ilg 2003). The recent relatives of Palaeoleuciscus are members of the freshwater genera Pseudophoxinus and Delminichthys (Böhme 1997; Perea et al. 2010), which today inhabit lakes, marshes and tributaries in the eastern Mediterranean and northern Africa (Anatolia, Levante, Tunisia and Algeria for Pseudophoxinus) and in the western Balkans (Croatia and Bosnia and Herzegovina for Delminichthys). The oldest known species is $P$. dietrichsbergensis from $\sim 19$ Ma old sediments (MN 3) in central Germany (Böhme 1993; Perea et al. 2010).

Genus Barbus Cuvier and Cloquet, 1816

\section{Barbus s.l.}

Figure 6i- $\mathrm{t}$

Material. 585 isolated pharyngeal teeth (LRNt-441-468, 481-973, 981-1037, 1041-1047); 72 lapilli (37 left: LRNl$2,8,9,32,40,41,113,119,122,134,135,150,151,209$, $212,216,223,238,239,260,283,284,286,301,303,304$, $311,320,321,331,348,355,358,359,362,371,388 ; 35$ right: LRNl-6, 23, 26, 31, 42, 43, 107, 121, 133, 139, 157, $158,215,218,231,243,247,250,254,274,276,288,305$, $314,319,322,338,339,347,351,352,353,357,368$, 389).

Description of pharyngeal dentition. 215 teeth (LRNt601-640, 836-973, 981-1037, 1041-1047) are molariform/mammiliform, as defined by Böhme (2002). There is a large variation in size, with the larger teeth being almost round with a slight elevation at the centre and the smaller molariform teeth being more oval-shaped with a distinct peak at the highest point (Fig. 6i, j). This tooth morphology characterises the anteriormost tooth position in the external tooth row (A5 or A4) of barbells.

A very large number of "hooked" teeth (as defined by Böhme 2002) show the typical Barbus-like morphology (Fig. 6k-p). There is very wide variation in size, but all teeth share a strongly bent hook and a longitudinally elongated and concave to slightly convex mastication area beneath it, which is bordered laterally by two short ridges. As in recent Barbus, the mastication area is more symmetrical and wider in posterior teeth of the external tooth row (A1 teeth, Fig. 6k, 1), narrower in more anterior teeth (A2/A3, Fig. 6n) and clearly asymmetrical in teeth from the middle and inner rows (Fig. 6m, o, p).

Description of lapilli. The strongest feature on the lapilli is the protruding, often pointed, posterolateral edge, which gives an elongated shape to most specimens (Fig. 6q-t). The anteromedial edge is rounded and well developed, sometimes anteriorly positioned, and often defined by a small incision anterior to it. The posteromedial edge is absent. The anterolateral edge is strong and the incision is deep, even in small specimens. The anterior margin is rounded, as is the margin between the anteromedial and posterolateral edges. The lateral margin is short and almost straight, and dorsoventrally undulated in the large specimens. The anterior portion of the lapilli is often longer than the posterior one. The convexity of the cranial umbo is rather strong in large lapilli. On the ventral side of the lapilli, the linea basalis is V-shaped, with a distinct continuous line in the lateral part and a less prominent line in the medial part, which is interrupted by a strong anteriorly directed angle (Fig. 6t). The measurements are given in Table 1.

Comparisons. Barbus is a highly heterodontous fish known from many Miocene localities in Eurasia. Fossil Barbus has so far been identified based on bones and/or pharyngeal dentition (e.g. Böhme 2002; Prieto et al. 2009). The absence of complete pharyngeal bones from the LRN material hinders detailed comparisons and the allocation of 
the material to a particular species. However, the described tooth morphologies closely resemble Barbus sensu stricto. The genus Luciobarbus can be excluded because of the absence of spatulate tooth morphologies (Böhme 2002). No living western Eurasian barbel known to us shows identical morphology and heterodonty to the Lesvos teeth (especially regarding the strong molarization of the anterior tooth position). However, eastern Balkan and western Anatolian species such as B. cyclolepis and B. prespensis are more comparable, although there are even some features in common with the tooth morphology of schizothoracin cyprinids (Böhme personal observations).

Schulz-Mirbach and Reichenbacher (2006) were the first to attribute seven barbin lapilli from the Middle Miocene (MN 8) locality Sofça in Turkey to aff. Barbus sp. (determination still based on coexisting pharyngeal tooth). The strong similarity of the LRN lapilli to lapilli of the extant Barbus barbus and those of the fossil aff. Barbus sp. from Sofça (both described by Schulz-Mirbach and Reichenbacher 2006) is mainly based on the strong antero- and posterolateral edges, the deep incision, the somewhat anterior position of the anteromedial edge, and the absent posteromedial edge.

Comments. The genus Barbus first appeared in Europe during the latest Early Miocene (MN 4b, Reichenbacher and Böhme 2004), and was very common during the early Middle Miocene. However, detailed investigations are lacking so far and systematic relationships to schizothoracin cyprinids remain elusive for these earliest of European barbells. In any case, neither the Early Miocene Barbus? sp. from Saudi-Arabia (Otero and Gayet 2001) nor the "Barbus" bohemicus Laube 1900 from the Czech Republic belong to Barbus s.str. (Böhme, personal observation).

Fossil Barbus species are mostly interpreted as indicators of streaming waters and fluvial environments (Prieto et al. 2009).

\section{Genus Cyprinion Heckel, 1843}

\section{Cyprinion sp.}

Figure $7 \mathrm{a}-\mathrm{e}$

Material. One left pharyngeal bone fragment with four teeth (LRNt-55); 397 isolated pharyngeal teeth (LRNt$1-52,56-400)$

Description of pharyngeal dentition. The pharyngeal bone fragment LRNt-55 preserves four teeth arranged in two rows, two in each (Fig. 7a). A third internal tooth row was most probably present but was broken off. The external tooth row shows the most posterior A1 tooth and the anteriorly following A2 tooth. The A1 tooth is $0.61 \mathrm{~mm}$ wide. In posterior view, the tooth is trapezoid, i.e. distally distinctly wider than proximally. Its longitudinal axis is slightly bent and the flat and anterior convex occlusal surface is narrowly teardrop-shaped with the thicker side internally. The occlusal surface is oriented perpendicular to the tooth axis (also on isolated teeth). The A2 tooth has largely the same morphology as the A1 tooth, with the exception of being less trapezoid (distally narrower, distal width $0.52 \mathrm{~mm}$ ) and anteroposteriorly thicker (i.e. broad teardrop-shaped). The middle tooth row preserves the B1 and B2 teeth. The B1 tooth is rather cylindrical (distally narrow, distal width $0.35 \mathrm{~mm}$ ) and longitudinally bent. Its grinding surface is slightly convex, so that the anterior side bears a diminished tip. The B2 has a flat grinding surface perpendicular to the tooth axis; its shape is almost triangular (distal width $0.42 \mathrm{~mm}$ ), with the point of the anteroposterior maximum inclined slightly internally. The enameloid of each tooth is thicker on the anterior wall than on the posterior one and bears deep anteroposterior scratches on both walls which never continue on the dentine. Furthermore, the anterior wall is higher than the posterior one, possibly because the thick enameloid of the anterior wall wears down at a slower pace than the thinner enameloid of the posterior wall.

The LRN material includes a very large number of isolated pharyngeal teeth that show a similar morphology to the four teeth on the LRNt-55 pharyngeal bone (Fig. 7be). Some of them can easily be recognised as A1 (Fig. 7b), A2 (Fig. 7c) or B1 (Fig. 7d) teeth; others are even more cylindrical and anteroposteriorly thick and may correspond to A3 or A4 teeth (Fig. 7e). The sizes of the pharyngeal bone and isolated teeth indicate a small-sized species, with a maximum total body length ranging from 10 to $15 \mathrm{~cm}$.

Comparison. The pharyngeal bone fragment LRNt-55 resembles the genus Cyprinion Heckel, 1843 in the following features: (1) teeth with teardrop-shaped occlusal surface perpendicular to the tooth axis, (2) heterodonty from posterior to anterior teeth, (3) A2 more cylindrical, distally narrower and anteroposteriorly thicker than A1, (4) B1 cylindrical with diminished anterodistal tip, and (5) small body size. It differs from the recent $C$. kais (and resembles C. macrostomus), in which the A4 tooth is hooked and the A5 tooth is molariform (Böhme, personal observation). It differs from C. macrostomus (and agrees with C. kais), in which the A1 and B1 teeth are more strongly bent, so that the posterior faces of these teeth bear a longitudinal groove (Böhme, personal observation). Isolated pharyngeal teeth of Cyprinion may be potentially misidentified as Palaeocarassius teeth (Böhme 2010); the latter differ in the presence of an occlusal surface which is oblique to the longitudinal axis (internally inclined) and by a strongly molariform A5 tooth. Furthermore, Palaeocarassius bears pharyngeal teeth in one row only (Böhme 2010). 


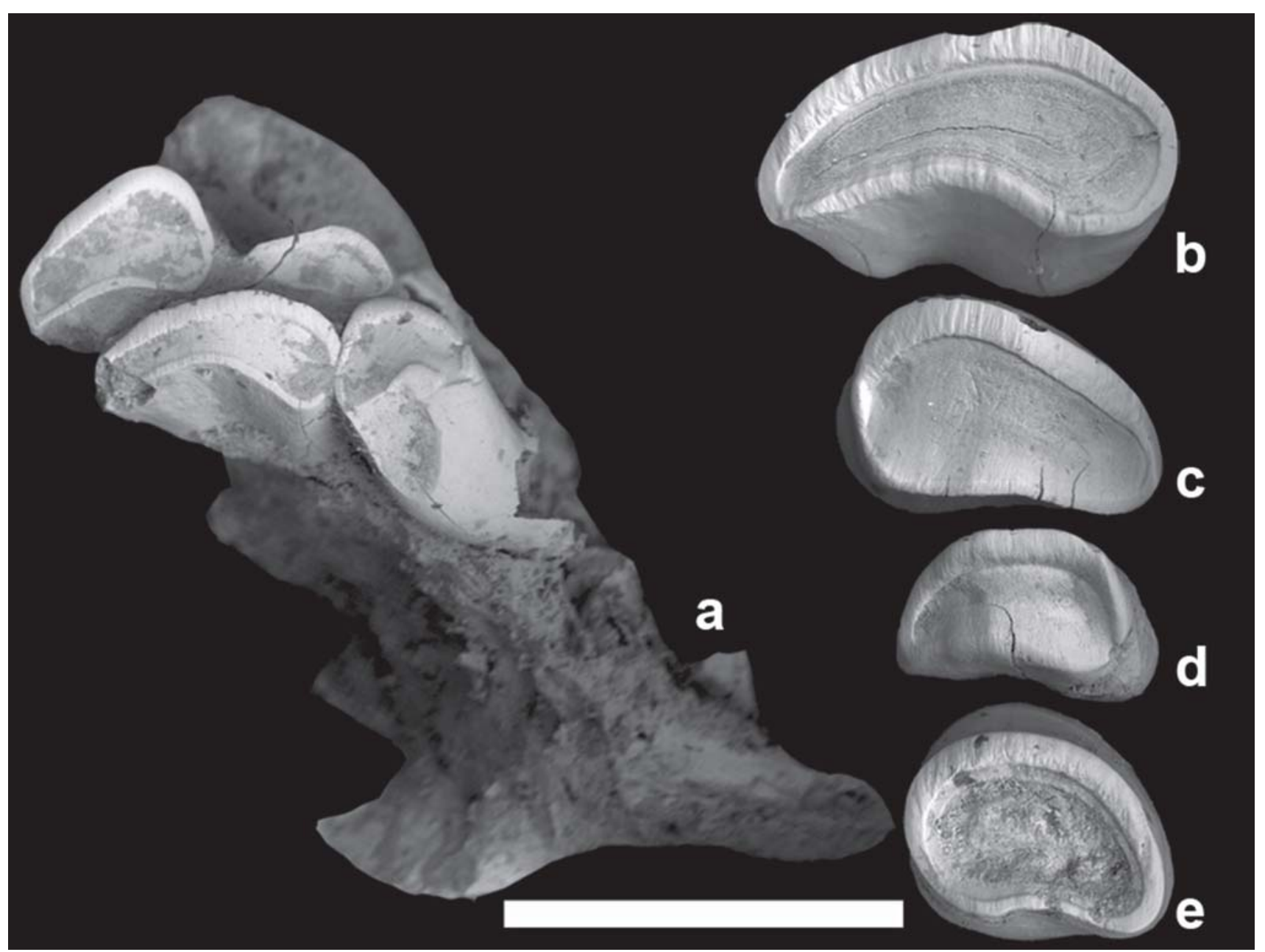

Fig. 7 Freshwater fish remains from Lapsarna, Lesvos Island, Greece; pharyngeal teeth in occlusal view unless otherwise specified. Cyprinion sp.: $a$ LRNt-55, left pharyngeal bone with A1, A2, B1 and

B2; $b$ LRNt-279, left A1; $c$ LRNt-347, right A2; $d$ LRNt-57, left B1; $e$ LRNt-67, right $\mathrm{B}$. Scale bar equals $1 \mathrm{~mm}$

Comments. Cyprinion Heckel, 1843 is a western Asian genus of small-sized barbin fishes that occupy rivers and tributaries (Alkan Uçkun and Gökçe 2015). According to Banarescu and Herzig-Straschil (1995), the distribution of the eight recent species comprises the northern (Orontes, Qweiq and Tigris-Euphrates drainage basins; C. macrostomus species group) and the southern (southern Arabian Peninsula, southern and central Iran, Afghanistan, and Pakistan west of the Indus river; C. watsoni-microphthalmus species group) parts of western Asia. Although it is the first time that fossil records of Cyprinion have been described, isolated pharyngeal teeth resembling the LRN material are known as aff. Cyprinion from early Middle Miocene sediments of western Anatolia (Dumlupınar, Calikli localities: reported as Varicorhinus/Capoeta by Böhme and Ilg 2003). According to Böhme et al. (2003), aff. Cyprinion characterizes period B (Late BurdigalianMiddle Serravallian, MN 4-MN 6, 18-13.5 Ma) of the Anatolian freshwater fish evolution. The early Miocene

Cyprinion from Lesvos might represent a new species, which, however, should only be named based on articulated skeletons. The genus Cyprinion is also the only barbel group in western Eurasia that has seven branched anal fin rays, instead of the five typical of nearly all barbins (Banarescu and Herzig-Straschil 1995). The Early Miocene (MN 3) species "Barbus" bohemicus Obrhelova, 1967 is described as having seven branched anal fin rays (Obrhelova 1967), which makes a generic attribution within Cyprinion most plausible. Also, based on its short dorsal fin ray (7-9 branched fin rays), it strongly resembles the southwestern Asian species group $C$. watsonimicrophthalmus.

Amphibia Linnaeus, 1758

Caudata Scopoli, 1777

Urodela Duméril, 1805

? Proteidae Gray, 1825

? Mioproteus Estes and Darevsky, 1977 


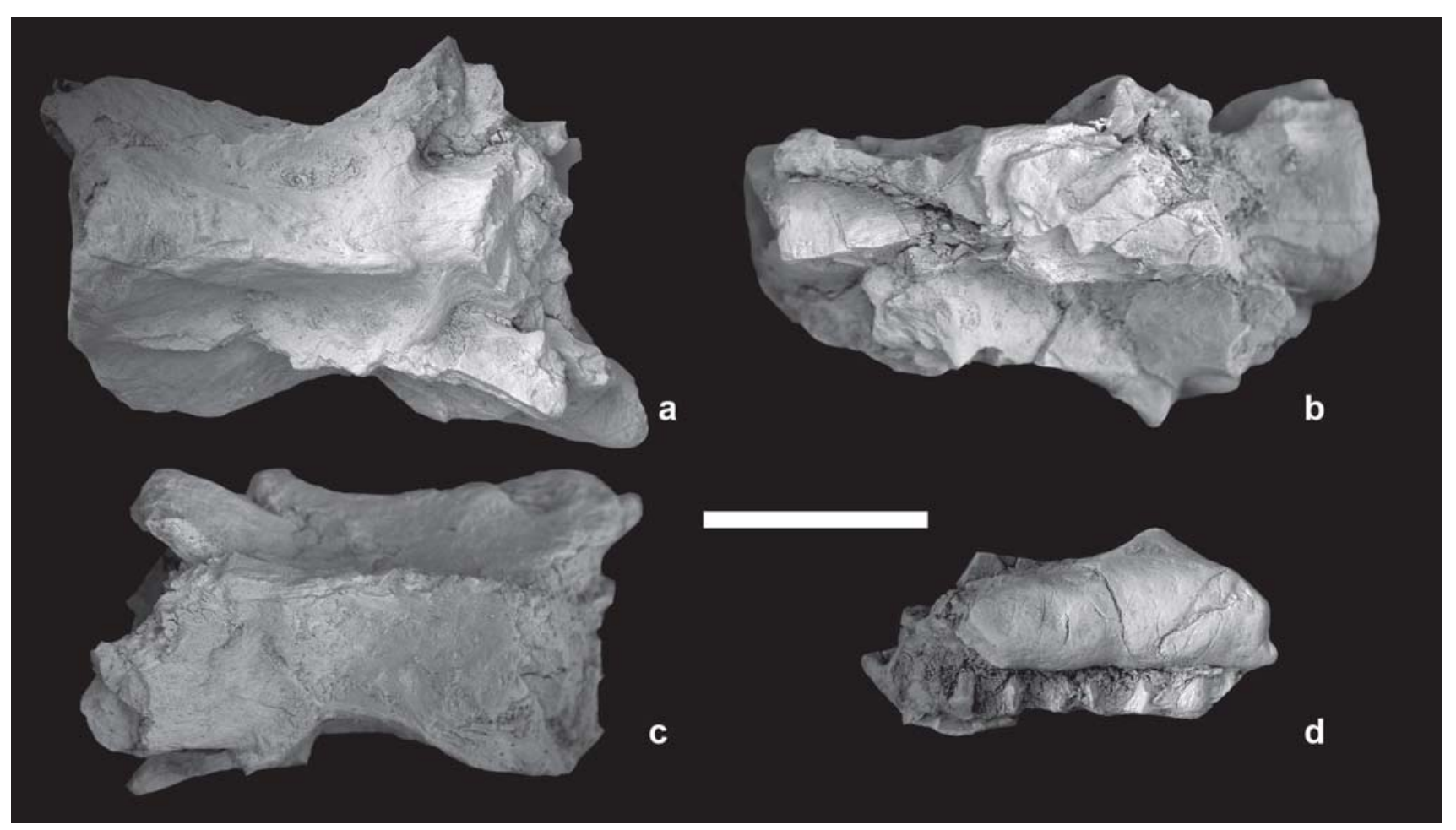

Fig. 8 Amphibian remains from Lapsarna, Lesvos Island, Greece. ? Mioproteus sp.: a-b LRNa-2249, trunk vertebra ( $a$ ventral view; $b$ dorsal view); $\boldsymbol{c}$ LRNa-2248, trunk vertebra (lateral view); Anura indet.: $d$ LRNa-2253, maxillary fragment (lingual view). Scale bar equals $1 \mathrm{~mm}$

\section{? Mioproteus sp.}

Figure $8 \mathrm{a}-\mathrm{c}$

Material. Eight incomplete trunk vertebrae (LRNa2244-2251).

Description. These trunk vertebrae are amphicoelous and rather elongated (Fig. 8a-c). The centrum is partially preserved, whereas most of the processes are damaged. No robust posterior basapophyses can be determined with certainty. The subcentral keel is rather prominent. The neural spine is totally damaged in all vertebrae.

Comments. The morphology of the elongated, robust and well-ossified vertebrae from Lapsarna is reminiscent of the genus Mioproteus, originally described from the Miocene of the Caucasus region (Estes and Darevsky 1977) and since then also found in the Miocene of the Czech Republic (Ivanov 2008) and Germany (Estes and Schleich 1994), as well as in the Pliocene of Poland (Młynarski et al. 1984) and France (Bailon 1995). However, in the absence of complete diagnostic material (e.g. vertebrae with robust posterior basapophyses), we can only tentatively assign the Lesvos salamandrid to this genus.

Salientia Laurenti, 1768

Anura Fischer von Waldheim, 1813
Anura indet.

Figure 8d

Material. One maxillary fragment (LRNa-2253).

Description. The maxillary fragment is toothless and retains only a small part of the jaw bone with a quite robust lamina horizontalis (Fig. 8d).

Comments. This single frog element is incompletely preserved and no diagnostic characters are present that would allow a more precise taxonomic identification. Furthermore, affinities with the widespread Latonia can be excluded, as no distinctive sculpturing is present on the maxillary bone in labial view (Roček 1994).

Reptilia Laurenti 1768

Crocodylia Gmelin, 1789

Crocodylia indet.

Figure 9a-d

Material. 70 isolated teeth (LRNr-2001-2070); one osteoderm (LRNr-2282).

Description. The teeth vary in size and shape, some are large, pointed and slender, some others are short-crowned and more robust. They all are, nevertheless, conical, with wrinkled enamel and moderately sharp anterior and 


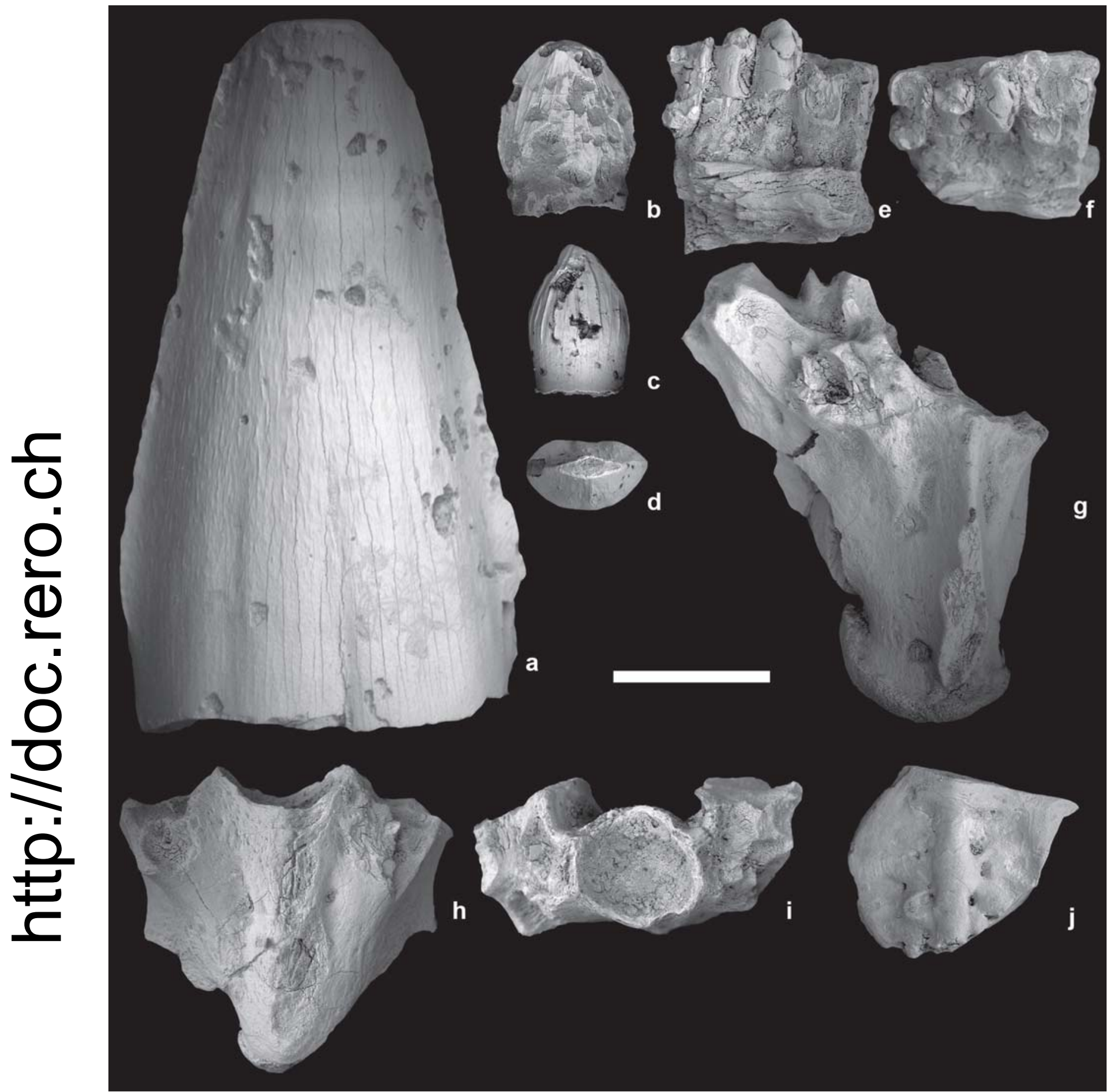

Fig. 9 Reptilian remains from Lapsarna, Lesvos Island, Greece. Crocodylia indet.: a-d isolated teeth: $a$ LRNr-2071 (lingual view); $b$ LRNr-2057 (lingual view); $c$ LRNr-2058 (buccal view); $d$ LRNr2059 (occlusal view); Lacertidae indet.: LRNr-2255, dentary fragment (e lingual view; $f$ dorsal view); ? Natricinae indet.: $g$ LRNr-

posterior carinae. Some teeth show a constriction near the basis of the crown (Fig. 9b) and some show a lingually bent crown (Fig. 9d). The isolated osteoderm has a flat
2275, trunk vertebra (ventro-lateral view); Serpentes indet.: LRNr2276, trunk vertebra ( $h$ ventral view; $i$ anterior view); Squamata indet.: $j$ LRNr-2281, osteoderm (dorsal view). Scale bar equals $1 \mathrm{~mm}$

ventral surface, bears a longitudinal keel, and its external surface is covered by ornamentation with relatively deep round pits. 
Comments. The LRN teeth have the general morphology of crocodylian teeth, with an overall conical shape and wrinkled enamel. Unfortunately, isolated crocodylian teeth are not diagnostic for more precise taxonomic identification (Delfino et al. 2007; Georgalis et al. 2016a) and, as such, the Lesvos specimens are here considered to represent an indeterminate crocodylian. Nevertheless, the new finds from Lapsarna represent only the second published record of crocodiles from Greece, as this clade has otherwise only been previously described from the Late Miocene of Crete (Georgalis et al. 2016a), whereas in Turkey this clade has been recorded from several Oligo-Miocene localities (e.g. Sen et al. 2011).

Squamata Oppel, 1811

Lacertidae Oppel, 1811

Lacertidae indet.

Figure 9e-f

Material. One dentary fragment (LRNr-2255).

Description. The dentary is rather fragmentary, with only four tooth positions preserved, as well as part of the subdental shelf and Meckel's groove. Two teeth are adequately preserved and appear to be tricuspid, whereas the two other teeth are severely damaged. The dentition is pleurodont. All teeth protrude well above the labial wall of the dentary. The subdental shelf is relatively robust and wide.

Comments. The general shape of the dentary fragment, the pleurodont dentition and the tricuspid teeth allow the identification of this element as a lacertid lizard (Estes et al. 1988; Gauthier et al. 2012). It should be noted that a pleurodont dentition combined with tricuspid teeth also appears in another lizard clade, the pleurodont "iguanids", extinct representatives of which have been recovered from the Paleogene of western Europe (Augé 2005; Smith 2009). However, the arrangement of the cusps on the teeth of lacertids and pleurodont "iguanids" is rather different (Čerňanský et al. 2016). The arrangement of the cusps on the LRN specimen is more consistent with that of lacertids. Due to the poor preservation of the only known specimen, comparison with known lacertids from other Greek Miocene localities, i.e. from Maramena (Richter 1995) and Ano Metochi (Georgalis et al. 2016b), cannot be made.

Serpentes Linnaeus, 1758

Alethinophidia Nopcsa, 1923

Colubridae Oppel, 1811

? Natricinae Bonaparte, 1838 (sensu Szyndlar, 1991a)

? Natricinae indet.

Figure $9 \mathrm{~g}$

Material. One precloacal vertebra (LRNr-2275).
Description. The vertebra is rather incomplete, missing both postzygapophyses, the left prezygapophysis, left synapophysis, neural arch, neural spine, zygosphene and cotyle. The vertebra is much longer than wide. Only the right synapophysis is partially preserved, and it appears that it is divided into diapophysis and parapophysis. The right prezygapophysis is also incompletely preserved and, as such, the exact shape and extent of the prezygapophyseal articular facets and the prezygapophyseal accessory cusps cannot be determined. In ventral view, remnants of a probable hypapophysis are visible.

Comments. The shape of the vertebra (longer than it is wide) and the probable presence of an hypapophysis denote probable affinities with natricine snakes. The absence of any sign of lymphapophyses, haemapophyses or pleurapophyses and the overall size of the vertebra indicate that it originates from the trunk region. Apart from natricines, the presence of an hypapophysis throughout the trunk vertebral column is also a characteristic of viperids and elapids (Szyndlar 1991a, b); however, based on its overall shape, we tentatively refer the Lapsarna specimen to natricines. In any case, the fragmentary nature of the material precludes any comparison with the other currently known Miocene natricines from Greece (Szyndlar 1995; Georgalis et al. 2016a).

\section{Serpentes indet.}

Figure 9h, i

\section{Material. One trunk vertebra (LRNr-2276).}

Description. The vertebra is rather incomplete, missing both postzygapophyses, the right prezegapophysis, neural arch, neural spine, zygosphene and zygantrum. Both synapophyses are severely damaged, as is the left prezygapophysis. The vertebra is relatively wide. In anterior view, the cotyle is rounded and rather large. In ventral view, a relatively large subcentral foramen lies in the left part of the centrum. No hypapophysis is present.

Comments. The fragmentary nature of the vertebra precludes the determination of its exact affinities. The absence of a hypapophysis, lymphapophyses, haemapophyses or pleurapophyses, along with its overall size, indicate that the vertebra most probably originates from the trunk region. Its general shape, being short and relatively wide, the shape of the synapophyses, and the absence of an hypapophysis hint at booid affinities. More specifically, affinities with erycines (sand boas) cannot be ruled out. Sand boas still occur in the extant herpetofauna of Lesvos (Valakos et al. 2008); however, taxonomic identification of this clade relies mostly on the complex morphology of their caudal vertebrae (Szyndlar 1991b). We prefer to refer this material to Serpentes indet., pending the recovery of more complete 
specimens from Lapsarna. However, this implies the presence of a second snake taxon aside from the probable natricine described above.

Squamata indet.

Figure $9 \mathrm{j}$

Material. One osteoderm (LRNr-2281).

Description. The osteoderm is rather small, with all its margins broken. The ornamentation consists of several deep pits across its surface. A prominent medial ridge runs along its entire preserved portion.

Comments. On the basis of this single element, it is impossible to determine the exact taxonomic affinities of this taxon. The morphology of the osteoderm does not seem to pertain to lacertids, and it appears possible that it belongs to Anguidae, a lizard clade that still occurs in Lesvos (Valakos et al. 2008) and was also present in the Miocene of Greece (Georgalis et al. 2016b). However, the possibility that it pertains to another lizard clade cannot be ruled out.

\section{Discussion}

\section{Faunal composition}

The layer sampled in the area of Lapsarna has revealed an exceptionally large number of mollusc remains. However, the vast majority are small, unidentifiable fragments, and even the "most complete" ones only consist of a rather small portion of the original shell (with the exception of the slug vestigial shells). Furthermore, most of the identifiable shells are moderately to strongly compressed, leading to the moderate to complete distortion of the initial shapes and dimensions. The shell fragmentation and distortion were possibly caused by the weight of the pyroclastic material that accumulated and deposited above the lake deposits during the initial phase of the volcanic activity in western Lesvos, when these lake sediments were still unconsolidated. Despite the bad condition of the fossil material, we could identify at least 11 taxa (Table 2).

The exceptionally rich fish material from Lapsarna (>1000 specimens in total) includes a large number of pharyngeal teeth originating from at least three species (Palaeoleuciscus sp., Barbus s.l. and Cyprinion sp.), as well as lapilli originating from the former two species (fossil lapilli of Cyprinion are still unknown) (Table 2). The material also includes a very large number of isolated fish bones, as well as other lapilli which cannot, however, be attributed to a taxon due to the absence of diagnostic features. The nature of the fossiliferous sediments and the sampling method would not allow the recovery of complete skeletons, even if some were present in the layer.

The amphibian and reptile fossil remnants are less common than those of the freshwater gastropods and fish. Only a few of them are recognisable (some vertebrae, maxillary and dentary fragments, osteoderms and isolated teeth), and they indicate the presence in the fauna of ? Mioproteus sp., Anura indet., Crocodylia indet., Lacertidae indet., ? Natricinae indet., Serpentes indet. and Squamata indet. (Table 2). It is possible that the LRN fossil material also includes other amphibian and reptile taxa, but elements from them are completely unidentifiable due to heavy fragmentation.

Finally, further sampling by the first author (K.V.) confirms the presence of the dormouse Glirulus diremptus in the micromammalian assemblage. The complete fauna from Lapsarna is presented in Table 2.

Table 2 Faunal list of the Early Miocene locality of Lapsarna, Lesvos (micromammalian taxa follow Vasileiadou and Zouros 2012, modified following the discovery of additional glirid material)

\begin{tabular}{|c|c|c|}
\hline Class & Family/clade & Species \\
\hline \multirow[t]{11}{*}{ Gastropoda } & Bithyniidae & Bithynia sp. \\
\hline & Emmericiidae & Emmericia sp. \\
\hline & Hydrobiidae & ? Bania sp. \\
\hline & & Hydrobiidae indet. \\
\hline & Lymnaeidae & ? Radix sp. \\
\hline & & Lymnaeidae indet. \\
\hline & Planorbidae & Gyraulus sp. \\
\hline & & Planorbarius sp. \\
\hline & Helicidae & Helicidae indet. \\
\hline & Milacidae & Milax sp. \\
\hline & Limacidae & Limax sp. \\
\hline \multirow[t]{3}{*}{ Actinopterygii } & Cyprinidae & Palaeoleuciscus sp. \\
\hline & & Barbus s.l. \\
\hline & & Cyprinion sp. \\
\hline \multirow[t]{2}{*}{ Amphibia } & ? Proteidae & ? Mioproteus sp. \\
\hline & Anura & Anura indet. \\
\hline \multirow[t]{5}{*}{ Reptilia } & Crocodylia & Crocodylia indet. \\
\hline & Lacertidae & Lacertidae indet. \\
\hline & Colubridae & ? Natricinae indet. \\
\hline & Serpentes & Serpentes indet. \\
\hline & Squamata & Squamata indet. \\
\hline \multirow[t]{7}{*}{ Mammalia } & Chiroptera & Chiroptera indet. \\
\hline & Erinaceidae & Erinaceidae indet. \\
\hline & Talpidae & Talpidae indet. \\
\hline & Soricidae & Soricidae indet. \\
\hline & Muridae & Eumyarion aff. latior/weinfurteri \\
\hline & & Democricetodon sp. \\
\hline & Gliridae & Glirulus diremptus \\
\hline
\end{tabular}




\section{Age of the fauna}

The absence of identifiable species from the LRN gastropod and ectothermic vertebrate material does not allow the determination of a more exact age for the fossiliferous layer than the one already known from the co-occurring micromammalian assemblage. Only the LRN fishes can give some rudimentary biostratigraphical information. Palaeoleuciscus sp. and Barbus sp. coexist in the Bavarian localities Burtenbach (Abdul Aziz et al. 2010) and Attenfeld (Reichenbacher et al. 2004), both of Karpatian age, and Untereichen-Altenstadt $565 \mathrm{~m}$, with an early Badenian age (Prieto et al. 2009). In general, species of the two genera seem to coexist in the western Paratethys during the Karpatian (upper part of MN 4b to lower part of MN 5), and during the early Badenian (middle part of MN 5) Cyprinion vel Capoeta is also present (Böhme and Reichenbacher 2003).

The gastropod and ectothermic vertebrate fossil record in the area of the southern Balkans and the eastern Mediterranean is very fragmentary (see below), thus excluding the possibility of correlating the LRN fauna with already known faunas. However, the radiometric age that can be attributed to the overlying pyroclastic material (PePiper and Piper 1993) suggests that the fossiliferous layer is most probably older than $18.4 \pm 0.5 \mathrm{Ma}$ (Vasileiadou and Zouros 2012). The basic biostratigraphical observations for the LRN fish genera fit well with this age, which can also be assumed for the LRN gastropod and ectothermic vertebrate fossil fauna.

\section{Palaeobiogeography}

The Early Miocene freshwater gastropod faunas of the Aegean-Anatolian region are poorly known (Neubauer et al. 2015). Gastropods did not diversify within several lake systems, such as the lakes in Chios and Aliveri-Kymi in Greece and Denizli, Harmancık and Urla in western Turkey before the latest Early Miocene to the Middle Miocene (Neubauer et al. 2015). Therefore, the present findings constitute some of the oldest freshwater gastropod faunas of the area.

At the family and genus level, the gastropod fauna shows considerable similarities to coeval assemblages of the Dinaride Lake System. Both regions share the presence of the truncatelloids Bithynia, Emmericia and Bania along with the pulmonate genera Gyraulus, Planorbarius and Radix. Emmericia and Bania are particularly diverse and likely originate in the Dinaride Lake System (e.g. Neubauer et al. 2013a, 2013b, 2016).

The younger and more diverse gastropod assemblages reported from the geographically close Chios Island by Schütt and Besenecker (1973) apparently have little in common with the present fauna. The only potential match may be with the Planorbarius and Radix species, while none of the many truncatelloids, neritids and unionid bivalves known from Chios were detected. A more thorough analysis of the molluscs' biogeographical relationships is still pending and requires identification at the species level and thus better-preserved material.

Reports on the presence of cyprinids in the Early to Middle Miocene of the southern Balkans are thus far limited and fragmentary, with only one representative of the family in most localities. Based on otoliths and teeth, Reichenbacher and Böhme (2004) inferred the presence of Barbus in the Middle Miocene lacustrine Nenita Fm of Chios (Greece). The only other Early to Middle Miocene cyprinid from Greece is the report of "aff. Barbinae" from the Early Miocene (MN 4) locality of Aliveri (Evia Island) (Böhme and Ilg 2003). In the Balkan area, Palaeoleuciscus has been reported from a few Late Oligocene to Middle Miocene localities of Bulgaria (Gaudant and Vatsev 1997, 2006) and the Early Miocene of the Cacak-Kraljevo Basin in Serbia (with two species; Gaudant 1998), whereas Barbus has only been reported from one Middle Miocene locality of Bulgaria (Nedialkovo and Kojumdshieva 1983). The reports from Turkey are more numerous, and the Early to Middle Miocene localities are richer in cyprinid species, with some of them revealing up to five species, including species of Palaeoleuciscus and Barbus (for more details about localities and cyprinid faunas, see the fosFARbase: Böhme and Ilg 2003).

The Early to Middle Miocene amphibian and reptile record for the East Mediterranean area is even scarcer. Up to now, there has been no report of the presence of Mioproteus or any other proteid in the Balkans or in Turkey (Bailon 1995). Anuran fossils have been reported from only two Early to early Late Miocene Greek localities: Aliveri (MN 4, Evia Island; Rage and Roček 2003) and Plakias (earliest Late Miocene to lowest part of MN 9, Crete Island; Georgalis et al. 2016a), but from several Early to Middle Miocene Turkish localities (e.g. Eskikilcak, Harami, Karg1, Keseköy, Çandir, Ahlath Dere; for a complete list of anuran localities in Turkey, see the fosFARbase: Böhme and Ilg 2003). Crocodylian and squamate faunas from the Miocene of Greece and Turkey are insufficiently known as yet (e.g. Richter 1995; Szyndlar 1995; Sen et al. 2011; Georgalis et al. 2016a, b; Čerňanský et al. 2017). Unfortunately, the fragmentary nature of the Lesvos specimens hinders any attempt to infer biogeographical significance concerning these groups.

All of these data indicate that the Lapsarna gastropod and fish faunas are definitely the best-documented ones from the Early Miocene of the southern Balkans and the Aegean area. Furthermore, this is the first time that a rich lapilli material has been attributed to a fossil Barbus 
species with certainty, leading to a better understanding of the intraspecific morphological variation. Regarding the herpetofauna from Lapsarna described herein, the new finds add to the already known diversity of Early Miocene reptiles from Greece, which previously consisted only of the pleurodire turtle Nostimochelone lampra from Nostimo (Georgalis et al. 2013; Georgalis and Kear 2013), the pythonid Python euboicus from Kymi (Römer 1870) and the chamaeleonid Chamaeleo cf. andrusovi from Aliveri (Georgalis et al. 2016c).

\section{Palaeoenvironment}

The Lapsarna fossil material may be poorly preserved, but studying it provides important information on the compositions of the gastropod and ectothermic vertebrate communities in the eastern Mediterranean area during the end of the Early Miocene. Most of the identified freshwater gastropod genera prefer slow-moving to standing waters and are often associated with rich vegetation. This suggests a lacustrine environment, and is in accordance with previous lithostratigraphic studies (Hecht 1974; Mourouzidou 2001). While Palaeoleuciscus was most probably part of the fish community of the local lake, Barbus and Cyprinion likely inhabited tributaries in the area.

The presence of an anuran and a salamandrid in Lapsarna further hints at an aquatic environment. This conclusion is further supported by the probable presence of a grass snake (Natricinae), a clade that mostly inhabits semiaquatic environments (Vitt and Caldwell 2014). All extant Crocodylia live in various aquatic habitats in tropical and subtropical areas (Martin 2008). Since a similar ecology is usually attributed to extinct crocodylians (e.g. Böhme 2003), the presence of crocodiles in Lesvos around $19 \mathrm{Ma}$ indicates that it had a tropical to subtropical climate at that time. This observation fits well with the palaeoenvironmental reconstructions already available for the area based on the fossil flora, which suggest that the area had a subtropical climate during the Early Miocene (e.g. Velitzelos et al. 1981a, b; Velitzelos and Zouros 1998).

Acknowledgements We are grateful to the Laboratory of Geology and Palaeontology and its Director, Prof. George Koufos (Department of Geology, Aristotle University of Thessaloniki, Greece), for access to the equipment and premises of the Lab. The help of Bettina Reichenbacher (Department of Earth and Environmental Sciences, Ludwig-Maximilians University, Munich) concerning the fish otoliths and her permission to access comparative material belonging to the Bavarian State Collection for Palaeontology and Geology (Munich, Germany) are very much appreciated. We thank Herbert Binder and Mathias Harzhauser (both of the Natural History Museum Vienna) for comments on the terrestrial snail fauna. Finally, we thank Massimo Delfino (University of Torino), Andrej Čerňanský and Jozef Klembara (Comenius University of Bratislava), an anonymous reviewer, and Mike Reich (Editor-in-Chief of Paläontologische Zeitschrift) for their valuable comments. This paper is a contribution to the project
"Freshwater systems in the Neogene and Quaternary of Europe: Gastropod biodiversity, provinciality, and faunal gradients", supported by the Austrian Science Fund FWF (project no. P25365-B25).

\section{References}

Abdul Aziz, H., M. Böhme, A. Rocholl, J. Prieto, J.R. Wijbrans, V. Bachtadse, and A. Ulbig. 2010. Integrated stratigraphy and 40Ar/ 39Ar chronology of the early to middle Miocene Upper Freshwater Molasse in western Bavaria (Germany). International Journal of Earth Sciences 99: 1859-1886.

Alkan Uçkun, A., and D. Gökçe. 2015. Growth and reproduction of Cyprinion macrostomus (Heckel, 1843) and Cyprinion kais (Heckel, 1843) populations in Karakaya Dam Lake (Euphrates River), Turkey. Turkish Journal of Zoology 39: 685-692.

Assis, C.A. 2005. The utricular otoliths, lapilli, of teleosts: their morphology and relevance for species identification and systematics studies. Scientia Marina 69: 259-273.

Augé, M. 2005. Evolution des lézards du Paléogène en Europe. Publications Scientifiques du Muséum. Mémoires du Muséum national d'Histoire naturelle, Paris 192: 1-369.

Bailon, S. 1995. Présence de Mioproteus (Amphibia, Proteidae) dans le Pliocène supérieur (MN 16) d'Europe de l'Ouest. Neues Jahrbuch für Geologie und Paläontologie, Monatshefte 1995 (1): 1-8.

Banarescu, P.M., and B. Herzig-Straschil. 1995. A revision of the species of the Cyprinion macrostomus-group (Pisces: Cyprinidae). Annalen des Naturhistorischen Museums in Wien 97(B): 411-420.

Binder, H. 2002. Die Land- und Süßwassergastropoden aus dem Karpatium des Korneuburger Beckens (Niederösterreich; Untermiozän). Beiträge zur Paläontologie 27: 161-203.

Binder, H. 2004. Terrestrial, freshwater and brachyhaline Gastropoda from the Lower Miocene deposits of Oberdorf (Styria, Austria). Annalen des Naturhistorischen Museums in Wien, Serie A 105: 189-229.

Binder, H. 2008. The systematic positions of the genera Pseudochloritis C. Boettger 1909 and Joossia Pfeffer 1929 (Gastropoda: Pulmonata: Helicoidea: Helicidae). Archiv für Molluskenkunde 137: 167-193.

Bleeker, P. 1859. Enumeratio specierum piscium hucusque in Archipelago indico observatarum, adjectis habitationibus citationibusque, ubi descriptions earum recentiores reperiuntur, nec non speciebus Musei Bleekeriani Bengalensibus, Japonicis, Capensibus, Tasmanicisque. Acta, Societas Indo-Neerlandense 6: $1-276$.

Böhme, M. 1993. Eine Untermiozäne Fischfauna (Teleostei, Cyprinidae) vom Dietrichsberg bei Vacha/Rhön. Freiberger Forschungshefte, Reihe C 450: 116-150.

Böhme, M. 1997. Revision der oligozänen und untermiozänen Vertreter der Gattung Palaeoleuciscus Obrhelova, 1969 (Teleostei, Cyprinidae) in Mitteleuropa. Dissertation. Leipzig: Universität Leipzig.

Böhme, M. 2002. Freshwater fishes from the Pannonian of the Vienna Basin with special reference to the locality Sandberg near Götzendorf, Lower Austria. Courier Forschungsinstitut Senckenberg 237: 151-173.

Böhme, M. 2003. The Miocene Climatic Optimum: evidence from ectothermic vertebrates of Central Europe. Palaeogeography, Palaeoclimatology, Palaeoecology 195 (3): 389-401.

Böhme, M. 2008. Ectothermic vertebrates (Teleostei, Allocaudata, Urodela, Anura, Testudines, Choristodera, Crocodylia, Squamata) from the Upper Oligocene of Oberleichtersbach (Northern Bavaria, Germany). Courier Forschungsinstitut Senckenberg 260: 161-183. 
Böhme, M. 2010. Ectothermic vertebrates (Actinopterygii, Allocaudata, Urodela, Anura, Crocodylia, Squamata) from the Miocene of Sandelzhausen (Germany, Bavaria) and their implications for environment reconstruction and palaeoclimate. Paläontologische Zeitschrift 84: 3-41.

Böhme, M., and A. Ilg. 2003. fosFARbase. http://www.wahre-staerke. com/. Accessed September-November 2014.

Böhme, M., and B. Reichenbacher. 2003. Teleost fishes from the Karpatian (Lower Miocene) of the Western Paratethys. In The Karpatian-an Early Miocene stage of the Central Paratethys, ed. R. Brzobohaty, I. Cicha, M. Kovac, and F. Rögel, 281-284. Brno: Masaryk University.

Böhme, M., B. Reichenbacher, and T. Schulz-Mirbach. 2003. Neogene Süsswasserfischfauna Anatoliens-ein Schlüssel zum Verständnis der (Palaeo-) Biogeographie europäischer Süsswasserfische. International Symposium of Fisheries and Zoology, Istanbul Abstract Volume: 9-10.

Bonaparte, C.L. 1838. Iconographia della fauna Italica per le quattro classi degli animali vertebrati. Vol. 2. Anfibi. Italy: Dalla Tipografia Salviucci.

Borsi, S., G. Ferrara, F. Innocenti, and R. Mazzuoli. 1972. Geochronology and petrology of recent volcanics in the eastern Aegean Sea (West Anatolia and Lesvos Island). Bulletin Volcanologique 36 (3): 473-496.

Bouchet, P., and J.-P. Rocroi. 2005. Classification and nomenclator of gastropod families. Malacologia 47 (1-2): 1-397.

Brochu, C.A. 2000. Phylogenetic relationships and divergence timing of Crocodylus based on morphology and the fossil record. Copeia 2000 (3): 657-673.

Brusina, S. 1870. Monographie der Gattungen Emmericia und Fossarulus. Verhandlungen der kaiserlichen und königlichen zoologisch-botanischen Gesellschaft in Wien 20: 925-938.

Brusina, S. 1874. Fossile Binnen-Mollusken aus Dalmatien, Kroatien und Slavonien nebst einem Anhange. Deutsche vemehrte Ausgabe der kroatischen im Rad der südslav. Akademie der Wissenschaften und Künstein Agram $(28,1874)$ erschienene Abhandlung, p. 143, Actienbuchdruckerei.

Brusina, S. 1896. Neogenska zbirka iz Ugarske, Hrvatske, Slavonije i Dalmacije na Budimpestanskoj izlozbi. Hrvatsko Naravoslovno Drutvo 9: 98-150.

Brusina, S. 1897. Gragja za neogensku malakološku faunu Dalmacije, Hrvatske i Slavonije uz neke vrste iz Bosne, Hercegovine i Serbije. Djela Jugoslavenske akademije znanosti i umjetnosti 18: $1-43$.

Bukowski, G.V. 1896. Die levantinische Molluskenfauna der Insel Rhodus (II. Theil. Schluss). Denkschriften der Kaiserlichen Akademie der Wissenschaften (Mathematisch-Naturwissenschaftliche Classe 63: 1-70.

Čerňanský, A., J. Klembara, and J. Müller. 2016. The new rare record of the late Oligocene lizards and amphisbaenians from Germany and its impact on our knowledge of the European terminal Palaeogene. Palaeobiodiversity Palaeoenvironments 96: 559-587.

Čerňanský, A., D. Vasilyan, G.L. Georgalis, P. Joniak, S. Mayda, and J. Klembara. 2017. The first records of fossil anguines (Squamata; Anguidae) from the Oligocene and Miocene localities of Turkey. Swiss Journal of Geosciences. doi:10.1007/s00015-0170272-5.

Clessin, S. 1877. Die tertiären Binnenconchylien von Undorf. Correspondenz-Blatt des Zoologisch-mineralogischen Vereins in Regensburg 31: 34-41.

Cope, E.D. 1887. Zittel's manual of palaeontology. The American Naturalist 21: 1010-1019.

Cuvier, G.L. 1798. Tableau élémentaire de l'histoire naturelle des animaux, 247. Paris: Baudoni.

Cuvier, G.L. 1817. Le regne animal. 2. Paris: Fortin, Masson et C. Librasis.
Cuvier G., and N. Cloquet. 1816. N. genus Barbus. In Dictionnaire national 2nd ed., vol 4(suppl.), 4. Strasbourg: F.G. Levrault.

de Charpentier, J. 1837. Catalogue des mollusques terrestres et fluviatiles de la Suisse. Formant la seconde partie de la faune Helvétique. Nouveaux Mémoires de la Société Helvétique des Sciences Naturelles 1: 1-28.

Delfino, M., M. Böhme, and L. Rook. 2007. First European evidence for transcontinental dispersal of Crocodylus (late Neogene of southern Italy). Zoological Journal of the Linnean Society London 149: 293-307.

Doukas, C.S. 2003. The MN4 faunas of Aliveri and Karydia (Greece). Coloquios de Paleontología 1: 127-132.

Duméril, A.M.C. 1805. Zoologie analytique, ou méthode naturelle de classification des animaux, rendue plus facile à l'aide de tableaux synoptiques. Paris: Allais.

Dunker, W. 1848. Ueber die in der Molasse bei Günzburg unfern Ulm vorkommenden Conchylien und Pflanzenreste. Palaeontographica 1: $155-168$

Ellis, R.A. 1926. British snails, 275. Oxford: Clarendon.

Estes, R. 1981. Caudata. In Handbuch der Paläoherpetologie, ed. P. Wellnhofer, 115. Stuttgart: Gustav Fischer Verlag.

Estes, R. 1983. Sauria Terrestria, Amphisbaenia. Encyclopedia of Paleoherpetology, part 10a. Stuttgart: Gustav Fischer Verlag.

Estes, R., and I. Darevsky. 1977. Fossil amphibians from the Miocene of the North Caucasus, USSR. Journal of the Palaeontological Society of India 20: 164-169.

Estes, R., K. de Queiroz, and J.A. Gauthier. 1988. Phylogenetic relationships within Squamata. In Phylogenetic relationships of the lizard families: essays commemorating Charles L. Camp, ed. R. Estes, and C.L. Camp, 119-281. Stanford: Stanford University Press.

Estes, R.D., and H.H. Schleich. 1994. New material of Mioproteus caucasicus Estes \& Darewsky from South German Localities (Amphibia: Cudata: Proteidae). Courier Forschungsinstitut Senckenberg 173: 7-21.

Férussac, A.E.J., and D.E. d'Audebard. 1822. Tableaux systématiques des animaux mollusques classés en familles naturelles, dans lesquels on a établi la concordance de tous les systèmes; suivis d'un prodrome général pour tous les mollusques terrestres ou fluviatiles, vivants ou fossils, 90. Paris: Arthus Bertrand.

Fischer von Waldheim, G. 1807. Muséum Demidoff, ou Catalogue systématique et raisonné des curiosités de la nature et de l'art donées à l'Université Impériale de Moscou par son excellence Monsieur Paul de Demidoff. Tom. 3. Végétaux et animaux. Moscou: Imprimerie de Université Impériale de Moscou.

Fischer von Waldheim, G. 1813. Zoognosia. Tabulis Synopticis Illustrata. Usum Praelectionum Academiae Imperialis MedicoChirurgicae Mosquensis Edita, Ed. 3, vol. 1. Moscow: Nicolai Sergeidis Vsevolozsky.

Frauenfeld, G. 1864. Vorläufige Aufzählung der Arten der Gattungen Hydrobia Htm. und Amnicola Gld. Hldm. in der kaiserlichen und in Cuming's Sammlung. Verhandlungen der ZoologischBotanischen Gesellschaft in Wien 13: 1017-1032.

Gaál, S. 1911. Die sarmatische Gastropodenfauna von Rákosd im Komitat Hunyad. Mitteilungen aus dem Jahrbuche der königlichen ungarischen Geologischen Reichsanstalt 18 (1): 1-111.

Gall, H. 1972. Die obermiozäne Fossil-Lagerstätte Sandelzhausen. 4. Die Molluskenfauna (Lamellibranchiata, Gastropoda) und ihre stratigraphische und ökologische Bedeutung. Mitteilungen der Bayerischen Staatssammlung für Paläontologie und Historische Geologie 12: 3-32.

Gaudant, J. 1998. The fish-fauna of Miocene continental waters from Serbia (Yugoslavia): a revision. Neues Jahrbuch für Geologie und Paläontologie, Abhandlungen 207 (1): 107-123.

Gaudant, J., and M. Vatsev. 1997. Nouvelles découvertes paléoichthyologiques dans l'Oligo-Miocène lacoustre du Sud-Ouest 
de la Bulgarie. Comptes Rendus de l'Académie des SciencesSeries IIA-Earth and Planetary Science 324 (10): 855-862.

Gaudant, J., and M. Vatsev. 2006. Une ichtyofaune lacustre dans le Miocène moyen du graben de Kjustendil (Bulgarie occidentale). Geodiversitas 28 (1): 55-70.

Gaudant, J., M. Weidmann, J.-P. Berger, T. Bolliger, D. Kälin, and B. Reichenbacher. 2002. Recherches sur les dents pharyngiennes de Poissons Cyprinidae de la Molasse d'eau douce oligo-miocène de Suisse (USM, OSM) et de Haute-Savoie (France). Revue de Paléobiologie 21 (1): 371-389.

Gauthier, J.A., M. Kearney, J.A. Maisano, O. Rieppel, and A.D.B. Behlke. 2012. Assembling the squamate tree of life: perspectives from the phenotype and the fossil record. Bulletin of the Peabody Museum of Natural History 53: 3-308.

Georgalis, G.L., and B.P. Kear. 2013. The fossil turtles of Greece: an overview of taxonomy and distribution. Geobios 46: 299-311.

Georgalis, G.L., E. Velitzelos, D. Velitzelos, and B.P. Kear. 2013. Nostimochelone lampra gen. et sp. nov., an enigmatic new podocnemidoidean turtle from the Lower Miocene of northern Greece. In Morphology and evolution of turtles: papers in honor of Eugene S Gaffney. Vol 3. Pleurodires, ed. D. Brinkman, P. Holroyd, and J. Gardner, 277-287. Dordrecht: Springer.

Georgalis, G.L., A. Villa, E. Vlachos, and M. Delfino. 2016a. Fossil amphibians and reptiles from Plakias, Crete: A glimpse into the earliest late Miocene herpetofaunas of southeastern Europe. Geobios 49: 433-444.

Georgalis, G.L., A. Villa, and M. Delfino. 2016b. Fossil lizards and snakes from Ano Metochi-a diverse squamate fauna from the latest Miocene of northern Greece. Historical Biology. doi:10. 1080/08912963.2016.1234619.

Georgalis, G.L., A. Villa, and M. Delfino. 2016c. First description of a fossil chamaeleonid from Greece and its relevance for the European biogeographic history of the group. The Science of Nature 103: 12.

Glöer, P. 2002. Die Tierwelt Deutschlands, 73. Teil: Die Süßwassergastropoden Nord- und Mitteleuropas. Bestimmungsschlüssel, Lebensweise, Verbreitung. Hackenheim: ConchBooks.

Gmelin, J.F. 1789. Regnum animal. Caroli a Linne Systema Naturae per regna tri naturae, secundum classes, ordines, genera, species, cum characteribus, differentiis, synonymis, locis, 1516 . Leipzig: Beer.

Golikov, A.N., and Ya.I. Starobogatov. 1975. Systematics of prosobranch gastropods. Malacologia 15: 185-232.

Gray, J.E. 1825. A synopsis of the genera of reptiles and amphibia, with a description of some new species. Annals of Philosophy 2 (10): 193-217.

Gray, J.E. 1840. Shells of molluscous animals. In Synopsis of the contents of the British Museum. London: British Museum.

Gray, J.E. 1855. Catalogue of Pulmonata or air breathing Mollusca in the collection of the British Museum. Part I. London: British Museum (Natural History).

Gray, J.E. 1857. Guide to the systematic distribution of Mollusca in the British Museum. Part I. London: Taylor \& Francis.

Harzhauser, M., and O. Mandic. 2008. Neogene lake systems of Central and South-Eastern Europe: faunal diversity, gradients and interrelations. Palaeogeography, Palaeoclimatology, Palaeoecology 260 (3): 417-434.

Harzhauser, M., T.A. Neubauer, M. Gross, and H. Binder. 2014a. The early Middle Miocene mollusc fauna of Lake Rein (Eastern Alps, Austria). Palaeontographica, Abt. A: PalaeozoologyStratigraphy 302 (1-6): 1-71.

Harzhauser, M., T.A. Neubauer, E. Georgopoulou, and J. Harl. 2014b. The Early Miocene (Burdigalian) mollusc fauna of the North Bohemian Lake (Most Basin). Bulletin of Geosciences 89 (4): 819-908.
Haszprunar, G., and G. Huber. 1990. On the central nervous system of Smeagolidae and Rhodopidae, two families questionably allied with the Gymnomorpha (Gastropoda: Euthyneura). Journal of Zoology London 220: 185-199.

Hecht, H. 1974. Geological map of Lesvos, 1:50.000. Athens: Institute of Geological and Mineralogical Research of Greece.

Heckel, J.J. 1843. Abbildungen und Beschreibungen der Fische Syriens. In Reisen in Europa, Asien und Afrika Bd. 1, T. 2, ed. J. Russegger, 991-1099. Stuttgart: Schweizerbart'sche Verlagsbuchhandlung.

Hoek Ostende, L.W. van den, S. Mayda, A. Oliver, A. Madern, V. Hernández-Ballarín, and P. Peláez-Campomanes. 2015. Aliveri revisited, a biogeographical appraisal of the early Miocene mammals from the eastern Mediterranean. Palaeobiodiversity and Palaeoenvironments 95 (3): 271-284.

Ivanov, M. 2008. Early Miocene Amphibians (Caudata, Salientia) from the Mokrá-Western Quarry (Czech Republic) with comments on the evolution of Early Miocene amphibian assemblages in Central Europe. Geobios 41: 465-492.

Jörger, K.M., I. Stöger, Y. Kano, H. Fukuda, T. Knebelsberger, and M. Schrödl. 2010. On the origin of Acochlidia and other enigmatic euthyneuran gastropods, with implications for the systematics of Heterobranchia. BMC Evolutionary Biology 10 (1): 323. doi:10.1186/1471-2148-10-323.

Jost, J., D. Kälin, T. Schulz-Mirbach, and B. Reichenbacher. 2007. Late Early Miocene lake deposits near Mauensee, central Switzerland: fish fauna (otoliths, teeth), accompanying biota and palaeoecology. Eclogae Geologicae Helvetiae 99: 309-326.

Katsikatsos, G., G. Migiros, M. Triantaphyllis, and A. Mettos. 1986. Geological structure of the internal Hellines east Thessalysouthwest Macedonia, Euboea-Attica-northern Cyclades islands and Lesvos, 191-212. Athens: Institute of Geological and Mineral Exploration.

Kókay, J. 2006. Nonmarine mollusc fauna from the Lower and Middle Miocene, Bakony Mts, W Hungary. Geologica Hungarica, Series Palaeontologica 56: 3-196.

Koufos, G.D., N. Zouros, and O. Mourouzidou. 2003. Prodeinotherium bavaricum (Proboscidea, Mammalia) from Lesvos island, Greece; the appearance of deinotheres in the Eastern Mediterranean. Geobios 36: 305-315.

Lamarck, J.B.P.A. 1801. Systéme des animaux ans vertèbres, 432. Paris: Deterville.

Laube, G.C. 1900. Neue Schildkröten und Fische aus der böhmischen Braunkohleformation. Lotos 2 (2): 37-56.

Laurenti J. N. 1768. Josephi Nicolai Laurenti Austriaci Viennensis Medicum, exhibens Synopsin Reptilium emendatam cum Experimentis circa Venena et Antidota Reptilium Austriacorum, 211. Wien.

Leach, W. E. 1818. In Narrative of a journey in the interior of China, and of a voyage to and from that country, in the years 1816 and 1817; containing an account of the most interesting transactions of Lord Amherst's embassy to the court of Pekin, and observations on the countries which it visited, Vol. 1, ed. C. Abel, 1-420. London: Longman, Hurst, Rees, Orme and Brown.

Linnaeus, C. 1758. Systema naturae per regna tria naturae, secundum classes, ordines, genera, species, cum characteribus, differentiis, synonymis locis. Tomus 1. Laurentius Salvius, Holmiae.

Martin, S. 2008. Global diversity of crocodiles (Crocodilia, Reptilia) in freshwater. Hydrobiologia 595 (1): 587-591.

Meyer, H. von. 1831. Mittheilung an geheimen Rath von Leonhard. Jahrbuch für Mineralogie 1831: 296-297.

Młynarski, M., Z. Szyndlar, R. Estes, and B. Sanchiz. 1984. Amphibians and reptiles from the Pliocene locality of Weze II near Dzialoszyn (Poland). Acta Palaeontologica Polonica 29: 209-227. 
Montfort, D.D. 1810. Conchyliologie systématique et classification méthodique de coquilles; offrant leurs figures, leur arrangement générique, leurs descriptions caractéristiques, leurs noms; ainsi que leur synonymie en plusieurs langues. Ouvrage destiné à faciliter l'étude des coquilles, ainsi que leur disposition dans les cabinets d'histoire naturelle. Coquilles univalves, non cloisonnées. 2. Schoell, Paris.

Mourouzidou, O. 2001. Tectonics and stratigraphy of the Neogene deposits of Gavathas area, Lesvos. M.Sc. Thesis, Aristotle University of Thessaloniki (in Greek).

Nakajima, T. 1984. Larval vs. adult pharyngeal dentition in some Japanese cyprinid fishes. Journal of Dental Research 63 (9): $1140-1146$.

Nedialkovo, N., and E. Kojumdshieva. 1983. Stratigraphy of the overlying sediments in the Est-Mariza browncoal basin. Review of the Bulgarian Geological Society 44 (3): 259-265.

Neubauer, T.A., O. Mandic, and M. Harzhauser. 2011. Middle Miocene freshwater mollusks from Lake Sinj (Dinaride Lake System, SE Croatia; Langhian). Archiv für Molluskenkunde 140: 201-237.

Neubauer, T.A., O. Mandic, M. Harzhauser, and H. Hrvatović. 2013a. A new Miocene lacustrine mollusc fauna of the Dinaride Lake System and its palaeobiogeographic, palaeoecologic, and taxonomic implications. Palaeontology 56 (1): 129-156.

Neubauer, T.A., O. Mandic, and M. Harzhauser. 2013b. The Middle Miocene freshwater mollusk fauna of Lake Gacko (SE Bosnia and Herzegovina): taxonomic revision and paleoenvironmental analysis. Fossil Record 16: 77-96.

Neubauer, T.A., M. Harzhauser, A. Kroh, E. Georgopoulou, and O. Mandic. 2014. The FreshGEN Database: Freshwater Gastropods of the European Neogene. http://www.marinespecies.org/fresh gen. Accessed summer 2016.

Neubauer, T.A., M. Harzhauser, A. Kroh, E. Georgopoulou, and O. Mandic. 2015. A gastropod-based biogeographic scheme for the European Neogene freshwater systems. Earth-Science Reviews 143: $98-116$

Neubauer, T.A., O. Mandic, and M. Harzhauser. 2016. The freshwater mollusk fauna of the Middle Miocene Lake Drniš (Dinaride Lake System, Croatia): a taxonomic and systematic revision. Austrian Journal of Earth Sciences 108 (2): 15-67. doi:10. 17738/ajes.2015.0013.

Nitz, B. 2013. Integrative systematics and biogeography of Limax (Gastropoda: Stylommatophora). Doctoral dissertation. München: Fakultät für Biologie der Ludwig-MaximiliansUniversität München.

Nopcsa, F. 1923. Die Familien der Reptilien. Fortschritte der Geologie und Paläontologie 2: 1-210.

Obrhelova, N. 1967. Cyprinoidei (Pisces) aus dem Hangenden des miozänen Braunkohleflözes Nordböhmens. Palaeontographica 126 (A): 141-179.

Obrhelova, N. 1969. Die Karpfenfische im tschechoslowakischen Süßwassertertiär. Casopis pro Mineralogii a Geologii 14 (1): 39-52.

Oppel, M. 1811. Die Ordnungen, Familien und Gattungen der Reptilien als Prodom einer Naturgeschichte derselben. München: Joseph Lindauer Verlag.

Otero, O., and M. Gayet. 2001. Paleoichthyofaunas from the Lower Oligocene and Miocene of the Arabian Plate. Palaeogeography, Palaeoclimatology, Palaeoecology 165 (1): 141-169.

Pasco-Viel, E., C. Charles, P. Chevret, M. Semon, P. Tafforeau, L. Viriot, and V. Laudet. 2010. Evolutionary trends of the pharyngeal dentition in Cypriniformes (Actinopterygii: Ostariophysi). PLoS One 5 (6): e11293. doi:10.1371/journal.pone. 0011293.

Pe-Piper, G. 1980. The Cenozoic volcanic sequence of Lesbos, Greece. Zeitschrift der Deutschen Geologischen Gesellschaft 131: 889-901.
Pe-Piper, G., and D.J.W. Piper. 1993. Revised stratigraphy of the Miocene volcanic rocks of Lesbos, Greece. Neues Jahrbuch für Geologie und Paläontologie, Monatshefte 2: 97-110.

Perea, S., M. Böhme, P. Zupančič, J. Freyhof, R. Šanda, M. Özuluğ, A. Abdoli, and I. Doadrio. 2010. Phylogenetic relationships and biogeographical patterns in circum-Mediterranean subfamily Leuciscinae (Teleostei, Cyprinidae) inferred from both mitochondrial and nuclear data. BMC Evolutionary Biology 10 (1): 265. doi:10.1186/1471-2148-10-265.

Prieto, J., M. Böhme, H. Maurer, K. Heissig, and H. Abdul Aziz. 2009. Biostratigraphy and sedimentology of the Fluviatile Untere Serie (Early and Middle Miocene) in the central part of the North Alpine Foreland Basin: implications for palaeoenvironment and climate. International Journal of Earth Sciences 98 (7): 1767-1791

Pyron, R.A., and J.J. Wiens. 2011. A large-scale phylogeny of Amphibia including over 2,800 species, and a revised classification of extant frogs, salamanders, and caecilians. Molecular Phylogenetics and Evolution 61: 543-583.

Rafinesque, C. S. 1815. Analyse de la nature, ou tableau de l'univers et des corps organises. Palerme.

Rage, J.-C. 1984. Serpentes. In Encyclopedia of paleoherpetology, part 11, ed. P. Wellnhofer. Stuttgart: G. Fischer Verlag.

Rage, J.-C., and Z. Roček. 2003. Evolution of anuran assemblages in the Tertiary and Quaternary of Europe, in the context of palaeoclimate and palaeogeography. Amphibia-Reptilia 24: 133-177.

Reichenbacher, B., and M. Böhme. 2004. Fish remains (otoliths, teeth) from the Miocene of Chios (Greece)—new palaeobiogeographic and palaeoclimatic results. In Proceedings of the 5th International Symposium on Eastern Mediterranean Geology, 14-20 April 2004, Thessaloniki, 338-339. Thessaloniki: International Symposium on Eastern Mediterranean Geology.

Reichenbacher, B., M. Böhme, K. Heissig, J. Prieto, and A. Kossler. 2004. New approach to assess biostratigraphy, palaeoecology and past climate in the South German Molasse Basin during the Early Miocene (Ottnangian, Karpatian). Courier Forschungsinstitut Senckenberg 249: 71-89.

Richter, A. 1995. The vertebrate locality Maramena (Macedonia, Greece) at the Turolian-Ruscinian Boundary (Neogene). 3. Lacertilia (Squamata, Reptilia). Münchner Geowissenschaftliche Abhandlungen 28: 35-38.

Roček, Z. 1994. Taxonomy and distribution of Tertiary discoglossid (Anura) of the genus Latonia v. Meyer, 1843. Geobios 27: 717-751.

Römer, F. 1870. Über Python euboicus, eine fossile Riesenschlange aus tertiärem Kalkschiefer von Kumi auf der Insel Euboea. Zeitschrift der Deutschen Geologischen Gesellschaft 22: 582-590.

Salvador, R.B., and M.W. Rasser. 2014. The fossil pulmonate snails of Sandelzhausen (Early/Middle Miocene, Germany) (Hygrophila, Punctoidea and limacoids). Archiv für Molluskenkunde 143 (2): 187-202.

Salvador, R.B., M.W. Rasser, and O. Höltke. 2015. Fossil gastropods from Miocene Lake Randeck Maar and its hinterland (SW Germany). Neues Jahrbuch für Geologie und Paläontologie, Abhandlungen 277 (3): 251-273. doi:10.1127/njgpa/2015/0505.

Sanchiz, B. 1998. Salientia. In Encyclopedia of paleoherpetology, part 4, ed. P. Wellnhofer. Munich: Friedrich Pfeil.

Schniebs, K., P. Glöer, M.V. Vinarski, and A.K. Hundsdoerfer. 2011. Intraspecific morphological and genetic variability in Radix balthica (Linnaeus 1758) (Gastropoda: Basommatophora: Lymnaeidae) with morphological comparison to other European Radix species. Journal of Conchology 40 (6): 657-678.

Schulz-Mirbach, T., and B. Reichenbacher. 2006. Reconstruction of Oligocene and Neogene freshwater fish faunas-an actualistic 
study on cypriniform otoliths. Acta Palaeontologica Polonica 51: 283-304.

Schütt, H. 1964. Die Molluskenfauna eines reliktären Quellsees der südlichen Türkei. Archiv für Molluskenkunde 93 (5/6): 173-180.

Schütt, H., and H. Besenecker. 1973. Eine Molluskenfauna aus dem Neogen von Chios (Ägäis). Archiv für Molluskenkunde 103 (1/ 3): $1-29$.

Scopoli, I.A. 1777. Introductio ad historiam naturalem, sistens genera lapidum, plantarum, edt animalium hactenus detecta, caracteribus essentialibus donata, in tribus divisa, subinde ad leges naturae, 506. Pragae: Gerle.

Sen, S., P.O. Antoine, B. Varol, T. Ayyildiz, and K. Sözeri. 2011. Giant rhinoceros Paraceratherium and other vertebrates from Oligocene and middle Miocene deposits of the Kağızman-Tuzluca Basin, Eastern Turkey. Naturwissenschaften 98 (5): 407-423.

Smith, K. 2009. Eocene lizards of the clade Geiseltaliellus from Messel and Geiseltal, Germany, and the early radiation of Iguanidae (Reptilia: Squamata). Bulletin of the Peabody Museum of Natural History 50 (2): 219-306.

Steel, R. 1973. Crocodylia. In Encyclopedia of paleoherpetology, part 16, ed. O. Kuhn. Stuttgart: G. Fischer Verlag.

Stimpson, W. 1865. Researches upon the Hydrobiinae and allied forms: chiefly made from materials in the Museum of the Smithsonian Institution. Smithsonian Miscellaneous Collections 7: 1-59.

Szyndlar, Z. 1991a. A review of Neogene and Quaternary snakes of Central and Eastern Europe. Part II: Natricinae, Elapidae. Viperidae. Estudios Geológicos 47: 237-266.

Szyndlar, Z. 1991b. A review of Neogene and Quaternary snakes of Central and Eastern Europe. Part I: Scolecophidia, Boidae, Colubrinae. Estudios Geológicos 47: 103-126.

Szyndlar, Z. 1995. The vertebrate locality Maramena (Macedonia, Greece) at the Turolian-Ruscinian Boundary (Neogene). 4. Serpentes (Squamata, Reptilia). Münchner Geowissenschaftliche Abhandlungen 28: 35-39.

Unger, F. 1845. Synopsis plantarum fossilium. Bibliopolam: Lipsiae apud Leopoldum Voss.

Unger, F. 1847. Chloris protogaea. Leipzig: Beitrage zur Flora der Vorwelt.

Valakos, E.D., P. Pafilis, K. Sotiropoulos, P. Lymberakis, P. Maragou, and J. Foufopoulos. 2008. Amphibians and reptiles of Greece. Frankfurt: Chimaira.
Vasileiadou, K., and N. Zouros. 2012. Early Miocene micromammals from the Lesvos Petrified Forest (Greece): preliminary results. Palaeobiodiversity and Palaeoenvironments 92 (2): 249-264.

Vavrova, L. 2010. Emmericia patula. The IUCN Red List of Threatened Species 2010: e.T155994A4880935. http://dx.doi. org/10.2305/IUCN.UK.2010-4.RLTS.T155994A4880935.en. Accessed on 28 September 2015.

Velitzelos, E., and N. Zouros. 1998. New results on the petrified forest of Lesvos. Bulletin of the Geological Society of Greece 32 (2): $133-142$.

Velitzelos, E., I. Petrescu, and N. Symeonidis. 1981a. Tertiäre Pflanzenreste von der aegaischen lnsel Lesvos (Griechenland). Courier Forschungsinstitut Senckenberg 50: 49-50.

Velitzelos, E., I. Petrescu, and N. Symeonidis. 1981b. Tertiäre Pflanzenreste aus Agais. Die Makroflora der lnsel Lesvos (Griechenland). Annales Géologiques des Pays Helléniques 30: $500-514$.

Vitt, L.J., and J.P. Caldwell. 2014. Herpetology. An introductory biology of amphibians and reptiles, 4th ed. Amsterdam: Academic, Elsevier.

Wade, C.M., P.B. Mordan, and F. Naggs. 2006. Evolutionary relationships among the Pulmonate land snails and slugs (Pulmonata, Stylommatophora). Biological Journal of the Linnean Society 87: 593-610.

Welter-Schultes, F.W. 2012. European non-marine molluscs, a guide for species identification. Göttingen: Planet Poster Editions.

Willmann, R. 1981. Evolution, Systematik und stratigraphische Bedeutung der neogenen Süßwassergastropoden von Rhodos und Kos/Ägäis. Palaeontographica 174: 10-235.

Zouros, N., E. Velitzelos, E. Valiakos, and K. Ververis. 2004. Submarine petrified forest in Lesvos Greece. In Proceedings of the 5th International Symposium on Eastern Mediterranean Geology, 14-20 April 2004, Thessaloniki, 437-440. Thessaloniki: International Symposium on Eastern Mediterranean Geology.

Zouros, N., E. Velitzelos, I. Valiakos, and O. Labaki. 2007. The Plaka Petrified Forest Park in Western Lesvos-Greece. Bulletin of the Geological Society of Greece 40: 1880-1891. 